Andrews University

Digital Commons @ Andrews University

1997

\title{
A Suggested Methodology for Establishing Evangelistic Contact With the Upper Classes in Jamaica
}

Denton W. Rhone

Andrews University

Follow this and additional works at: https://digitalcommons.andrews.edu/dmin

Part of the Missions and World Christianity Commons

\section{Recommended Citation}

Rhone, Denton W., "A Suggested Methodology for Establishing Evangelistic Contact With the Upper Classes in Jamaica" (1997). Professional Dissertations DMin. 107.

https://dx.doi.org/10.32597/dmin/107

https://digitalcommons.andrews.edu/dmin/107

This Project Report is brought to you for free and open access by the Graduate Research at Digital Commons @ Andrews University. It has been accepted for inclusion in Professional Dissertations DMin by an authorized administrator of Digital Commons @ Andrews University. For more information, please contact repository@andrews.edu. 


\section{Andrews \$university}

Seek Knowledge. Affirm Faith. Change the World.

Thank you for your interest in the

\section{Andrews University Digital Library of Dissertations and Theses.}

Please honor the copyright of this document by not duplicating or distributing additional copies in any form without the author's express written permission. Thanks for your cooperation. 


\section{INFORMATION TO USERS}

This manuscript has been reproduced from the microfilm master. UMI films the text directly from the original or copy submitted. Thus, some thesis and dissertation copies are in typewriter face, while others may be from any type of computer printer.

The quality of this reproduction is dependent upon the quality of the copy submitted. Broken or indistinct print, colored or poor quality illustrations and photographs, print bleedthrough, substandard margins, and improper alignment can adversely affect reproduction.

In the unlikely event that the author did not send UMI a complete manuscript and there are missing pages, these will be noted. Also, if unauthorized copyright material had to be removed, a note will indicate the deletion.

Oversize materials (e.g., maps, drawings, charts) are reproduced by sectioning the original, beginning at the upper left-hand corner and continuing from left to right in equal sections with small overlaps.

ProQuest information and Learning

300 North Zeeb Road, Ann Arbor, MI 48106-1346 USA

800-521-0600

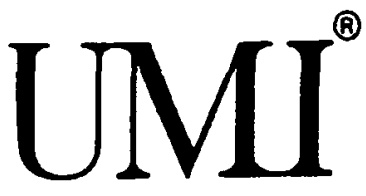


Reproduced with permission of the copyright owner. Further reproduction prohibited without permission. 


\title{
ABSTRACT \\ A SUGGESTED METHODOLOGY FOR ESTABLISHING EVANGELISTIC CONTACT WITH THE UPPER CLASSES IN JAMAICA
}

\author{
by \\ Denton $W$. Rhone
}

Adviser: Bruce L. Bauer 


\title{
ABSTRACT OF GRADUATE STUDENT RESEARCH \\ Dissertation
}

\author{
Andrews University \\ Seventh-day Adventist Theological Seminary
}

\begin{abstract}
Title: A SUGGESTED METHODOLOGY FOR ESTABLISHING EVANGELISTIC CONTACT WITH THE UPPER CLASSES IN JAMAICA
\end{abstract}

Name of researcher: Denton $\mathrm{W}$. Rhone

Name and degree of faculty adviser: Bruce L. Bauer, D.Miss. Date completed: September 1996

\section{Problem}

The Seventh-day Adventist Church was established in Jamaica in 1903. Since then, the church has grown with membership totalling 162,831 by 1995. In 1995, there were $2,500,000$ inhabitants in Jamaica, with 1 in 15 claiming to be a Seventh-day Adventist. Jamaicans can be divided into nine social classes; the Seventh-day Adventist Church has been successful in reaching mainly two of these classes, the poor and the lower-middle. Presently the SDA Church and the upper classes are insulated from each other. This dissertation suggests an approach to establish contact with the upper classes so that they can be reached with the SDA message. 


\section{Method}

The research shows that, while the method of evangelism commonly used in Jamaica is successful in reaching the lower classes, it has been ineffective in attracting or making contact with the upper classes. Intentional Ministries (any social ministry, instrument, or program created and designed by the church to make a deliberate impact within the local community) is suggested as a method of evangelism to establish contact with the upper classes and make the way possible for personal evangelism to take place.

\section{Significance}

There has never been a deliberate attempt by any denomination in the history of Jamaica to reach the upper classes with the gospel. The Seventh-day Adventist Church, in developing an approach to reach the upper classes, would be attempting a form of evangelism that is unprecedented not only in the SDA Church but in the history of all other denominations in Jamaica.

All people, groups, and classes need to be reached with the Seventh-day Adventist message; the upper classes are no exception. Intentional Ministries can be the bridge that the church can use to establish contact with the upper classes and make it possible for evangelization to take place. 
Reproduced with permission of the copyright owner. Further reproduction prohibited without permission. 


\title{
Andrews University \\ Seventh-day Adventist Theological Seminary
}

A SUGGESTED METHODOLOGY FOR ESTABLISHING

EVANGELISTIC CONTACT WITH THE

UPPER CLASSES IN JAMAICA

\author{
A Dissertation \\ Presented in Partial Fulfillment \\ of the Requirements for the Degree \\ Doctor of Ministry
}

by

Denton W. Rhone

September 1996 
UMI Number: 3096516

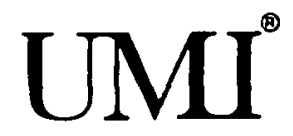

UMI Microform 3096516

Copyright 2003 by ProQuest Information and Learning Company.

All rights reserved. This microform edition is protected against unauthorized copying under Title 17, United States Code.

\section{ProQuest Information and Learning Company 300 North Zeeb Road \\ P.O. Box 1346 \\ Ann Arbor, MI 48106-1346}


Reproduced with permission of the copyright owner. Further reproduction prohibited without permission. 


\title{
A SUGGESTED METHODOLOGY FOR ESTABLISHING EVANGELISTIC CONTACT WITH THE UPPER CLASSES IN JAMAICA
}

\author{
A dissertation \\ presented in partial fulfillment \\ of the requirements for the degree \\ Doctor of Ministry
}

by

Denton w. Rhone

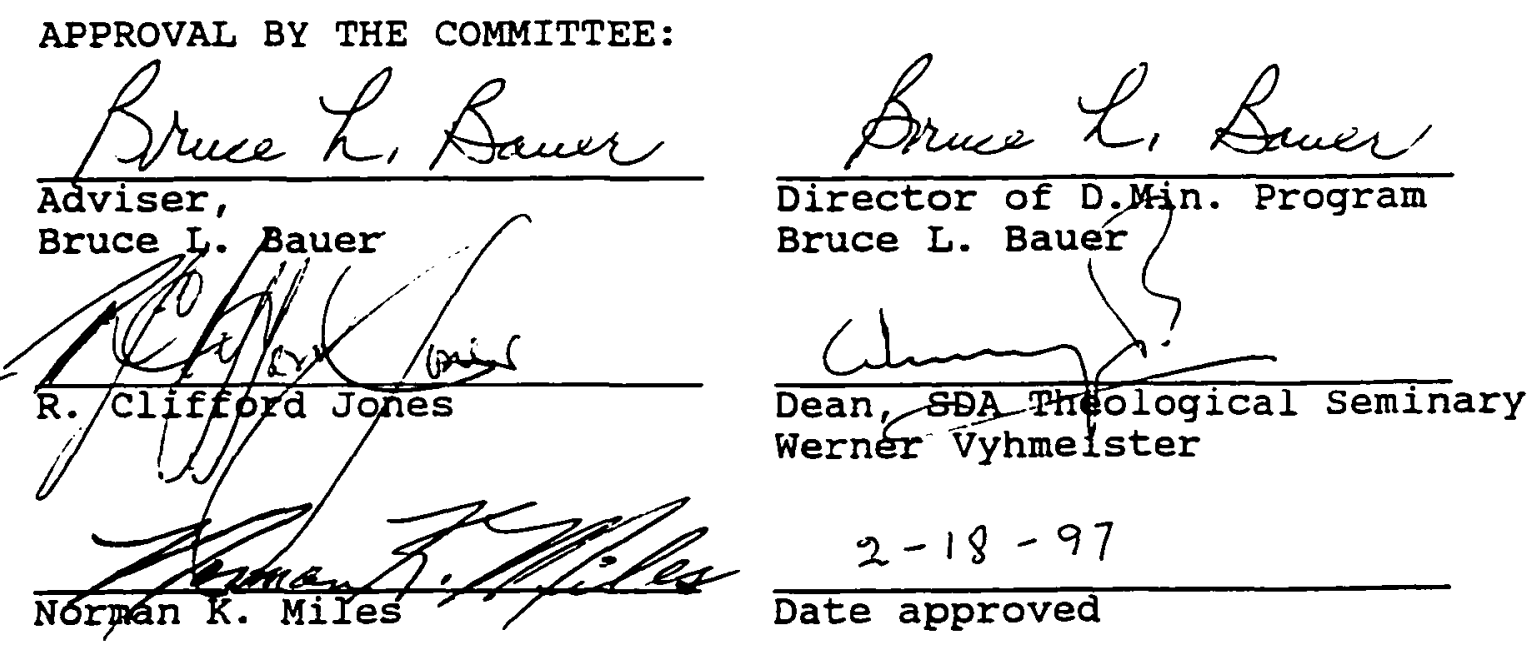




\section{DEDICATION}

\section{To the workers of Central Jamaica Conference and the members of the churches I have been privileged to serve}

\section{iii}

Reproduced with permission of the copyright owner. Further reproduction prohibited without permission. 
TABLE OF CONTENTS

LIST OF TABLES • • • • • • • • • • • • • • • • •

vii

ACKNOWLEDGMENTS

viii

Chapter

I. INTRODUCTION . . . . . . . . . . . . . . . . . 1

purpose of the study . . . . . . . . . . . . 1

Justification for the study . . . . . . . . 1

Description of the study . . . . . . . . . . 5

Sources and Methodology . . . . . . . . . 6

Limitations of the study . . . . . . . . . 6

II. JAMAICA AND THE IDENTIFICATION AND

DEFINITION OF ITS SOCIAL CLASSES . . . . . . . . 8

Jamaica: An Overview . . . . . . . . . 8

Population . . . . . . . . . . . . . 9

History . . . . . . . . . . . . . . . 9

Government and Politics . . . . . . . . 11

Education . . . . . . . . . . . . . . 12

Industries . . . . . . . . . . . . . . 14

People, Color, and class . . . . . . . 14

The Middle-Upper and Upper Classes: Values and Concerns . . . . . . . . . . . . . 25

Education . . . . . . . . . . . . . 27

Money . . . . . . . . . . . . . . 27

Family . . . . . . . . . . . . . . . 28

Ethnic Nationalism . . . . . . . . 29

Violence . . . . . . . . . . . . 30

Community Involvement . . . . . . . . . 31

Religion and Church . . . . . . . . 31

III. THE SEVENTH-DAY ADVENTIST CHURCH AND

THE SOCIAL CLASSES . . . . . . . . . . . . . . 34

The Seventh-day Adventist church in Jamaica:

Origin, Growth, and Impact . . . . . . 34

origin . . . . . . . . . . . . . . . 34

Which Classes Are Being Reached? . . . . 37

Why the Seventh-day Adventist Church

Is Not Reaching the Upper Classes . . . . 40

iv 
Historical Factors . . . . . . . . . 42

Perception . . . . . . . . . . . . . . 46

Secularization ............. 50

Institutional Evangelistic Practice . . . 55

Seventh-day Adventist Lifestyle and Culture . . . . . . . . . . 60

Theological Distinctives . . . . . . . 65

Materialism .. . . . . . . . . . . 66

Conclusion . . . . . . . . . . . . 67

IV. INTENTIONAL MINISTRIES AS A SUGGESTED

APPROACH FOR REACHING THE MIDDLE-UPPER

AND UPPER CLASSES . . . . . . . . . . . . . 69

The Need to Reach This Group . . . . . . . 69

Can They be Reached? . . . . . . . . . . . 72

Jesus and the Upper Classes . . . . . . 73

Intentional Ministries . . . . . . . . . 75

Definition . . . . . . . . . . . . 76

Social and community concerns . . . . . 77

Attempts at Resolution . . . . . . . . 79

Community Problems and the

Upper Classes . . . . . . . . . 80

The Role of the SDA Church . . . . . . 81

SDAs, Upper Classes, Lower Classes, and Intentional Ministries . . . . . 86

Purpose .. . . . . . . . . . . . 88

Will the Upper Classes Support

Intentional Ministries? . . . . . . 88

Summary . • . . . . . . . . . . . . . 92

Evangelistic Potential . . . . . . . . . 94

A Personal Testimony . . . . . . . . . 96

Relational Evangelism . . . . . . . . 97

Implementing the Strategy . . . . . . . . . 98

The Minister's Role . . . . . . . . . . . 98

Equipping the Laity . . . . . . . . . . 99

Community Leadership . . . . . . . . 102

Networking . . . . . . . . . . . . . . . 103

Creating Involvement . . . . . . . . 104

Evangelistic Opportunities . . . . . . . 106

Needed Skills . . . . . . . . . . . . 107

Relational . . . . . . . . . . . 107

Listening . . . . . . . . . . . . . 111

Civic Consciousness . . . . . . . . 112

Summary . . . . . . . . . . . . . . . . 113

V. SUMMARY, RECOMMENDATIONS, AND CONCLUSIONS • • • 115

Summary •. . • • • • • • • • • • • • • • 115

Recommendations . . . . . . . . . . . 118

The Conference . . . . . . . . . . . 118

The Pastor . . . . . . . . . . . . 123

$\mathbf{V}$ 
The Church . . . . . . . . . . . . 127

Conclusion . . . . . . . . . . . . . 130

APPENDIX . . . . . . . . . . . . . . . . . . . 133

BIBLIOGRAPHY . . . . . . . . . . . . . . . . 137

VITA • . . . . . . . . . . . . . . . . . . . 143

vi

Reproduced with permission of the copyright owner. Further reproduction prohibited without permission. 


\section{LIST OF TABLES}

1. Overall Ethnic Balance in Jamaica in 1938 . . . . 17

2. Race and Wealth, 1938 . . . . . . . . . . . . 18

vii 


\section{ACKNOWLEDGMENTS}

I wish to express heartfelt gratitude to the following individuals:

To my Lord Jesus Christ who has enabled me, because He considered me worthwhile, placing me into the ministry (1 Tim 1:12).

To Drs. Bruce Bauer and R. Clifford Jones. Their patience, encouragement, technical assistance, and confidence in me provided the energy I needed to see this project to completion.

To my mentor, Dr. Norman Miles, who embodies the model of Christian leadership I have chosen to emulate. His vision, lectures, and conversations helped provide the inspiration for this dissertation.

To my father, clinton Rhone, who through letters and countless telephone conversations provided needed companionship through this journey at Andrews. I cannot forget his constant counsel, "Don't you ever leave God's ministry."

To Mrs. Venetia Douce, for her support and faith in me, always encouraging me to "finish."

To the countless church members all across Jamaica and Fort Wayne, Indiana, for their prayers and love.

\section{viii}


To the indefatigable Bonnie Beres, who typed this entire manuscript.

To Senator Audly Shaw and his wife, Maureen. My association with them gave birth to the burden to labor for the conversion of the upper classes.

All glory belongs only to Him who has stayed away from us too long, the blessed Lord and Saviour Jesus Christ. 
CHAPTER 1

INTRODUCTION

\section{Purpose of the study}

As the Seventh-day Adventist Church in Jamaica moves into a new century, it will have to minister to the changing culture and subcultures in the country, and it will have to do so from an inclusive perspective. To provide spiritual leadership on a national level, the church will need members who are from the higher classes of the Jamaican society. The purpose of this study is to suggest an approach that can lead to converting people who are within the upper classes to the SDA message.

\section{Justification for the study}

There is a large and increasing middle- and upper-class population in Jamaica that is not being reached by the Seventh-day Adventist message. The few middle-class members in the church have been either those baptized from traditional Seventh-day Adventist middle-class families or youth from the church who progress because of education and 
have moved into a middle-class situation.' The large middle- and upper-middle classes in Jamaica remain mostly unaffected by the Seventh-day Adventist message.

The Seventh-day Adventist Church has been ministering in Jamaica for over one hundred years. ${ }^{2}$ During this period, evangelistic methods and strategies have been highly effective in reaching the poorer classes such as farmers, the semi-educated, unskilled individuals, and a few members of the lower-middle class. There has not been a deliberate study to formulate strategies to address this problem.

It is to the credit of the church that it has grown

over the past one hundred years to become one of the largest denominations on the island. The 1995 SDA Yearbook reveals that one of every fifteen Jamaicans claim the Seventh-day Adventist Church as their denominational affiliation. ${ }^{3}$ But while the church is numerically strong, it lacks the strong political, social, and financial influence of many other denominations. ${ }^{4}$ It is my assumption that one of the contributing causes for this is due to the lack of the

${ }^{1}$ This phenomenon in Christianity is discussed in chapter 16 of Donald McGavran's Understanding Church Growth (Grand Rapids, MI: Eerdmans Publishing Company, 1990).

${ }^{2}$ Seventh-day Adventist Yearbook (Washington, DC: General Conference of Seventh-day Adventists, 1904), 74 .

${ }^{3}$ Seventh-day Adventist Yearbook (Hagerstown, MD: Review and Herald Pub. Assn., 1995), 192-195.

${ }^{4}$ Donald McGavran made this observation in 1962 and it is still valid in 1996. See Donald McGavran, Church Growth in Jamaica (India: Lucknow Publishing House, 1962), 30. 
middle and upper classes in the Jamaican Seventh-day Adventist Church.

Raymond Bakke and David Claerbaut in their books, The Urban Christian and Urban Ministry, respectively, make it clear that the problem of large membership without a corresponding social, political, and financial influence is not only a Seventh-day Adventist problem. In carrying out their ministry, churches have had the tendency to ignore the urban and suburban communities.' While many churches are within these urban communities, they tend to be insular ${ }^{2}$ in regard to the felt needs and the core assumption of the urban upper classes. There are many influential professionals among the upper classes, and the Seventh-day Adventist church must reach them.

I have ministered within the Jamaican Seventh-day Adventist church for over eight years. During this time I have increasingly carried a burden for the salvation of young middle-class and upper-class professional colleagues. During the last four years of my ministry I have deliberately taken initiatives to reach out to this group. Surprisingly, I discovered that ministering to this group

'David Claerbaut, Urban Ministry (Grand Rapids, MI: Zondervan Publishing House, 1983), 189-198; Ray Bakke, The Urban Christian (Downers Grove, IL: InterVarsity Press, 1987), 45 .

${ }^{2}$ Bakke argues that the cause for this is that the "Christian community lives as though it were a ghetto," Bakke, 60 . 
was not as difficult as I was preconditioned to expect. I became a family friend of the local senator and member of Parliament. Encouraged by this, I reached out to other community leaders. These efforts resulted in my being asked to serve on the local hospital staff as chaplain for the School of Nursing. I was also invited to share regularly with the local Rotary Club, and asked to become a member of the influential ministerial fraternity of the community.

I also became the personal friend of an influential Catholic priest. When he was transferred, I was asked to replace him in many of his community-held offices. I discovered that the leaders within these outside and often unchurched communities, for the most part, held the seventhday Adventist Church in high esteem. The problem was that they had no authoritative information concerning seventh-day Adventists.

Another realization that I came to in my relationship with this community is that people within the middle and upper classes have needs, hopes, dreams, and fears like any other member of the human family and wished not to be viewed as just urban professionals or middle class and upper class, but as people.

The Lord calls the church to take the gospel to the entire world (Matt 28:18-20). The Adventist Church claims as its mission, best expressed in the Adventist youth motto, "the Advent message into all the world." The church's logo 
with the three angels' messages of Jesus Christ being carried into the world also underscores the church's mission: to take the gospel to all the world. The world includes the upper-middle and upper classes. The church must devise strategies to reach those it is not successful in reaching at the present time.

\section{Description of the study}

Chapter 2 of this study presents a brief overview of Jamaica and its classes. The chapter then focuses on the upper-middle and upper classes by describing their concerns and values. Chapter 3 briefly discusses the origin and growth of the Seventh-day Adventist Church in Jamaica and the classes that are being reached by the church. This chapter reflects the extensive interviews that were conducted with all the major Seventh-day Adventist leaders in Jamaica and also leading clergy of other major denominations. The purpose of the interviews was to discover how effective the denominations have been in reaching the upper-middle and upper classes in Jamaica. The chapter then discusses seven factors that are deterrents to the SDA Church reaching the secular rich in Jamaican society.

Chapter 4 suggests a strategy that can be effective in forming a "bridge"l between the insular SDA church and the

\footnotetext{
'John R. W. Stott, Christian Mission in the Modern World (Downers Grove, IL: InterVarsity Press, 1975), 80.
} 
insular secular rich in Jamaican society so that evangelism can take place. Chapter 5 is the summary and conclusion with recommendations that are necessary to be in place if the suggested approach is to be effective in reaching the secular rich.

\section{Sources and Methodology}

There are no known documented strategies or literature in the Jamaican situation that were directly relevant to the approach suggested by this study. Therefore, the information that formed the background of this study was drawn from several sources. Seeing that Jamaica is a country in the Western hemisphere, ministry in Jamaica is not unlike ministry in the United States, therefore books and articles written by American missiologists, pastors, and church leaders were consulted to inform the study. Books on sociological problems in Jamaica, written by Jamaicans in the United States and individuals in Jamaica, were also of special value.

In February 1996, I travelled to Jamaica and conducted personal interviews with all the major SDA leaders in Jamaica and leaders of non-SDA churches. As was mentioned, this forms the major authority for chapter 3 .

\section{Limitations of the study}

The approach suggested by this study for reaching the secular rich in Jamaica is theoretical. It was not 
convenient to implement this proposition in Jamaica while studying at Andrews. To implement an approach of this nature would evidently take time--months or even a year.

It is not the purpose of this study to suggest careful strategies of evangelism that will be effective in converting the upper class. In my experience with the upper classes, the methods of evangelism used to convert people of any class are operative and effective. Prayer, Bible study, spiritual leadership, and religious pastoral care and concern are needs experienced by the upper classes as well $i$ they respond to spiritual care and issues just like any other class. To assume that all the secular rich view "God as a hobby"' is erroneous. ${ }^{3}$

The major challenge in reaching the upper class is insularity. ${ }^{4}$ There is no contact between the upper classes in Jamaica and the SDA Church. This study limits itself to suggesting an approach that can provide a bridge between the upper classes and the SDA Church.

\footnotetext{
'Paul Johnson, an affluent journalist, made this confession in his book The Quest for God (New York: Harper Collins Publishers, 1996), 43-44.

'stephen Carter, The culture of Disbelief (New York: Harper Collins Publishers, 1993), 23-24.

${ }^{3}$ Ibid. , 37

${ }^{4}$ Bakke, 60; Claerbaut, 53 .
} 
CHAPTER 2

\section{JAMAICA AND THE IDENTIFICATION AND \\ DEFINITION OF ITS SOCIAL CLASSES}

This chapter presents a brief description of Jamaica along with a concise overview of the country's history, population, education, industry, and governance. The discussion then focuses on the Jamaican people and their class divisions, expanding on the middle- and upper-class communities. Towards the end of the chapter, the study looks at the religious interests of the middle and upper class.

\section{Jamaica: An Overview}

Jamaica is the third largest island of the Greater Antilles and the largest of the English-speaking islands of the Caribbean. The islands of the Caribbean are called the West Indian Archipelago. These are "tops of submerged mountain ranges linking the Americas."1 The country is approximately 4,411 square miles, with maximum dimensions of

\footnotetext{
${ }^{1} K$. E. Ingram, Jamaica, World Bibliographical Series, vol. 45 (Oxford, England: Clio Press, 1984), xvii.
} 
146 by 51 miles.' The north of the island consists of narrow plains with wider plains on the south. The interior, which forms most of the country, is comprised mainly of mountains and rivers. The highest mountain approximates 7,402 ft.

\section{Population}

The population figures taken from the April 7, 1991, census, as set out in the revised preliminary figures put out by Jamaica Statistical Institute, present the population of the country at $2,391,273 .^{2}$ In 1995, the Seventh-day Adventist Yearbook records the country's population at $2,500,000,3$ a growth of 108,627 in four years. Analysis revealed that the population has remained relatively constant since the mid-1970s, irrespective of the high birth rate. ${ }^{4}$ This perhaps is due to the high rate of immigration by the Jamaican people.

\section{History}

Jamaica's recorded history begins with the coming of Christopher Columbus in 1494. When Columbus and the spaniards arrived on the island it was already being

\footnotetext{
'The Gleaner Geography and History of Jamaica (Kingston: Gleaner Company, 1995), 2, 3 .

${ }^{2}$ Ibid. , 19

${ }^{3}$ Seventh-day Adventist Yearbook (1995), 184-187.

${ }^{4}$ Ingram, 19.
} 
occupied by a peaceful, primitive people called the Arawaks. These were a mild group of Indian settlers. They were "supposed to have been very hospitable towards the visiting Spaniards." The spaniards repaid the hospitality by exterminating these aboriginal inhabitants. "Horrifying accounts of Spanish brutality to these gentle people are given by historians of the period. In Hispaniola it is reported that the settlers frequently murdered Indians in sport." 2 The brutality continued until this race of people were eventually "exterminated under harsh Spanish rule and possible exposure to European diseases against which they had no immunity." ${ }^{3}$

In 1655, English soldiers attacked and conquered the Spanish settlers. The English brought with them their customs, religion, and political traditions. ${ }^{4}$ sugar was later introduced into the island and became a major export crop. To supply labor for the sugar plantations, slaves were imported from Africa. This practice was to continue until the emancipation of the slaves. August 1, 1834, is very significant in the history of Jamaica: the Emancipation Act freeing all slaves was passed in the now

\footnotetext{
'Stafford Earle, The Basic Jamaica Book (Ontario, Canada: ECI Publications, 1977), 14 .

${ }^{2}$ Clinton V. Black, The Story of Jamaica (London: Collins Clear Type Press, 1965), 14 .

'Ibid., 95.

${ }^{4}$ Ingram, 5 .
} 
11

British parliament. Blacks were now legally free. ${ }^{1}$ The country, however, was still to be governed as a colony. This continued for another 128 years. On August 6, 1962, Jamaica gained independence from British rule and became self-governing. Prior to independence August 1 was celebrated as Emancipation Day;

in the future; the first Monday in August is celebrated for both events, emancipation and independence being the two most significant events leading from a past of deprivation and despair to a future of hope, from inequality to equality, from bondage to freedom. ${ }^{2}$

Government and Politics

In 1962, the colony of Jamaica was organized as a constitutional monarchy; the Queen being represented by a governor general. The parliamentary government consists of the prime minister and a cabinet chosen from the majority party in parliament. There is predominantly a two-party system in Jamaica, the Jamaica Labor Party (JLP) and the Peoples' National Party (PNP). These two major political parties have exchanged control in the governance of the country several times since independence. The Peoples' National Party (PNP) has been the government since 1989.

\footnotetext{
'Wendell Bell, Jamaican Leaders (Los Angeles: University of California Press, 1964), 14.

I'Ibid., 45.
} 


\section{Education}

Errol Miller, former permanent secretary in the Ministry of Education, conducted and published a comprehensive research on education in Jamaica. This research reveals that since emancipation to 1985 , there has been accelerated growth in the provision of educational institutions. In Jamaica today there is one major university that was established in 1948,1141 schools in the public secondary sector, ${ }^{2}$ and 882 schools at the primary level. ${ }^{3}$ In addition to this there are also six public teacher-training colleges. ${ }^{4}$ Seventh-day Adventists also have a major liberal arts college on the island. It is to be noted that there are a number of secondary schools privately owned. "Currently the Seventh-day Adventist denomination operates the largest number of private secondary schools."

Education at the secondary sector is divided in the following manner:

1. New secondary schools

'Errol Miller, Jamaican Society and High Schooling (Kingston, Jamaica: Institute of Social and Economic Research, 1990), 187.

'Ibid., 209.

${ }^{3}$ Ibid. , 205.

${ }^{4}$ Patrick Allen, former Director of Education, West Indies Union, interview by author, August 6, 1996.

SMiller, 204. 
2. Comprehensive high schools

3. Vocational agricultural schools

4. Technical high schools

5. Traditional high schools.'

Presently "about 50 percent of the 12 to 17 age cohort [are] enrolled in some type of secondary school."2 In 1985, 349,541 students were enrolled at the primary level. ${ }^{3}$

What factors have contributed to this growth in emphasis on education in Jamaica seeing that in the early period the "ruling white minority. . opposed elementary education for blacks and secondary education for coloureds"?4 Various factors can be identified. With the introduction of the crown colony reform begun in the late 1800 s to "pacify black discontent," the way was cleared for education to emerge. ${ }^{6}$ Along with this, grants were provided to denominations for building new schools. Churches also provided large amounts of capital for the building of schools. ${ }^{7}$

$$
\begin{aligned}
& \text { 'Ibid., } 209 . \\
& { }^{2} \text { Ibid., } 208 . \\
& { }^{3} \text { Ibid., } 205 . \\
& { }^{4} \text { Ibid., } 55 . \\
& { }^{5} \text { Ibid., } 56 . \\
& { }^{6} \text { Ibid. } \\
& { }^{7} \text { Ibid., } 175 .
\end{aligned}
$$


In 1942, education was predominantly for the traditional higher classes, but with further reforms beginning in 1957, many lower-class students began matriculating into the educational system. These reforms matured in 1973 with the government making high school education free. ${ }^{1}$

\section{Industries}

Agriculture is one of the island's major industries. The primary economic crops are sugar, bananas, citrus, cocoa, coffee, coconuts, ginger, and peanuts. Bauxite and alumna are mined and exported, resulting in major income to the country. Tourism steadily developed to become the major income earner, surpassing bauxite.

\section{People, Color, and class}

Because of the traditional stratification of the country's slave heritage a "social system has resulted in which whites have been found at the top, blacks on the bottom and browns or colored . . . in the middle."2 Not only Jamaica, but all "slave societies developed characteristic color-class hierarchies which were enforced

\footnotetext{
'Ibid., 161.

${ }^{2}$ Irving Kaplan et al., Area Handbook for Jamaica (Washington, DC: American Press, 1976), 91.
} 
by forms of legal and extra-legal coercion and exclusions that were decisions to preserve white supremacy."1

After the emancipation of the slaves in 1834 until the pre-war era, the classes in Jamaica were identified along color lines. Whites, though in the minority with only 0.8 percent of the population, controlled the economic and political power of the country. They composed the upper class. Blacks, though in the majority with 78.5 percent of the country's population, were in the lower class. The traditional middle class with 15 percent, ${ }^{2}$ was the brown skinned, the offspring of Black and White relationships.

Whites held the position of upper class by token of their skin color. They were allowed to own land and pursue business. Blacks, being descendants of slaves, were kept "in their place"13 and kept at the bottom of the social ladder by being denied all the opportunities for advancement. ${ }^{4}$ The only opportunities blacks received was to be given plots of land to cultivate, and then they were

${ }^{1}$ Elza Berquo and Peter Xenos, eds., Family systems and
Cultural Change (New York: Oxford University Press, 1992), 26.

'The percentages are taken from one of Jamaica's leading historians, Rex Nettleford, Mirfor, Mirror (Kingston, Jamaica: Williams, Collins and Sangster Press, 1971). In this work Nettleford discussed the issue over several chapters.

${ }^{3}$ Abigail A. Bakan, Ideology and class conflict in Jamaica (Montreal, Quebec: McGill-Queen University Press, 1990), 6 .

$$
{ }^{4} \text { Ibid., } 9 .
$$


encouraged to sell their produce at the local market.' The browns came to inherit middle-class status. This was made possible by

the absentee nature of . . the planter class or plantocracy. The majority of the wealthy planters were residents in Britain. As a result, many service occupations that would normally have been preserved for the colonial ruler became open to residents in Jamaica, particularly the progeny of white male colonists and black female slaves. Management of the plantations, legal advising, maintaining correspondence, and the like, were prestigious tasks requiring certain acquired skilis offered to those of fairer complexion.2

While color played a major role in the classification of the classes, it would be misleading to view color as the only index of class identification in the Jamaican culture. There were several indexes of class: e.g., formal education. In the pre-war era formal education became a contributory factor of class distinction. In this period there existed practiced, unashamed inequality towards the education of the country's inhabitants. Rupert Lewis in his book, Marcus Garvey: His Work and Impact, wrote:

The level of opportunity beyond primary school was a reliable indicator of the extent of ethnic inequality in the society. . . . In the late 1930s, 62 percent of the Whites had experienced education beyond primary school. Among the more well-off Jewish and Lebanese intermediary ethnic groups, the level of post-primary educational exposure was 60 percent and 45 percent, respectively. The subordinate ethnic groups had the lowest level of post-primary education, which amounted

\footnotetext{
${ }^{1}$ Ibid.

${ }^{2}$ Ibid., 6 .
} 
to 1.5 percent for the Blacks and 2 percent for the Indians. ${ }^{1}$

The Blacks, in spite of being the majority race in the country, were kept in the lower class by being denied accessibility to formal education in proportion to the other ethnic groups.

Table 1 illustrates the inequality of the availability of education in correlation to other ethnic groups present in Jamaica at the time.

TABLE 1

OVERALL ETHNIC BALANCE

IN JAMAICA IN 1938

\begin{tabular}{|c|c|}
\hline Group & $\frac{8}{8}$ \\
\hline $\begin{array}{l}\text { Dominant Ethnic Group } \\
\text { White }\end{array}$ & 1 \\
\hline $\begin{array}{l}\text { Intermediary Ethnic Group } \\
\text { Browns }\end{array}$ & 17 \\
\hline $\begin{array}{l}\text { Chinese, Lebanese, Jews } \\
\text { Subordinate Ethnic Groups }\end{array}$ & 2 \\
\hline $\begin{array}{l}\text { Blacks } \\
\text { Indians }\end{array}$ & $\begin{array}{r}78 \\
2\end{array}$ \\
\hline Total & $100 \%$ \\
\hline
\end{tabular}

Source: Rex Nettleford, Mirror, Mirror (Kingston, Jamaica: William Collins and Sangster, 1971), 250.

'Rupert Lewis, Marcus Garvey: His Work and Impact (London, England: Collins Clear-Type Press, 1972), 27-29. 
Social stratification was also identifiable in terms of wealth. One of the primary sources of wealth was land. The land prior to 1943 was primarily owned by the White upper class. The colored, or Browns as they were called, had marginal ownership. There was virtually no land owned by the Black majority. Table 2 illustrates the relationship between race, class, and wealth.

\section{TABLE 2}

RACE AND WEALTH, 1938

Race and color Strata
$\%$ operating more than 100 acres
White

Colored

Black
43.3

4.9

.7

Source: Carl Stone, Class, Race and Political Behaviour (Kingston, Jamaica: Institute of Social and Economic Research, University of the West Indies, 1973), 9.

Since the 1962 contemporary stratification, the coming of the Rastafarian movement, the political dynamics in Jamaica during the 1970s, and economic conditions within the country, serious adjustments of the traditional class system have resulted. After independence in 1962, many white upper-class Jamaicans and expatriates migrated, creating a vacuum, especially in the political arena. This vacuum was 
filled by the so-called Browns or colored of the traditional middle class.'

\section{Rastafari Movement}

The pre-colonial and colonial heritage of Jamaica had introduced confusion in the cognitive life of the society. Whites clearly saw themselves as belonging to Europe. Whites controlled the political and economic life of the country. Arrogance became commonplace and this group came to view themselves and their culture as superior to any and all ethnic groups. Whatever was unlike the European culture, values, or belief system was considered as inferior. The Browns, belonging to the middle class, through education, sought acceptance from the culturally and economically dominant Whites. This education was primarily Euro-influenced. The Blacks were denied educational exposure, hence they continued to perceive themselves as inferior to the Browns and viewed the Whites as superior. ${ }^{2}$

Within this matrix the Rastafarian movement developed. The Rastafarian movement is an offshoot of Garveyism. Marcus Garvey was a Black nationalist leader of the early 1920s. Rastafarianism's "single most important hallmark is its rejection of Western culture, which Rastafarians claim

${ }^{1}$ Kaplan, 93.

${ }^{2}$ Barry Chevannes, The Case of Jah vs. Middle Class Society: Rastafari Exorcism of the Ideology of Racism in Jamaica (The Hague, Netherlands: Institute of Social Studies, 1989), 3 . 
rejects them because of their socio-economic status."

Rastafarians" behavior can best be explained "not in terms of personality systems, but in terms of the social system, i.e., the structure of social relations." Through reggae music the Rastafarians deliberately vocalize

strong sentiments against what they call (back then) 'brown man government' (protesting inequality of wealth distribution in Jamaica). Traditionally they have condemned the 'white bias' of Jamaican society--that is to say Eurocentrism. . . Without drastic class reorientation, the Rastas believe there is no future in Jamaica for them, or for that matter for the black lower class as a whole.

Black (was) equated with poverty and deprivation. And the Rastas have taken it upon themselves to make known this state of affairs. No other group has openly questioned the ruling standards or sought to project what they call 'The African personality.'

The Rastafarian movement significantly readjusted the country's self-perception in the context of color and class. Lower-class Jamaicans began to take pride in their own ethnicity and blackness. ${ }^{2}$ They began moving away from measuring their self-worth in the various shades of their skin color. The practice of comparing their sense of dignity and value as persons against Whites began to change. Jamaicans started looking at the strengths of their ethnicity in creative ways.

'Winston A. Thompson, "Reggae Music: An Effective Epistemology," Union Seminary Quarterly Review 36, no. 4 (Summer 1981): 264 .

${ }^{2}$ Barry Clevannes, Rastafari: Roots and Ideology (New York: Syracuse University Press, 1995), 145. 
Barry Chevannes, an authority on the study of the Rastafari movement in Jamaica, argues that it is in the context of race, color, and the promotion of Black nationalism that the impact of the Rastafari is to be evaluated.' Rex Nettleford, a major Jamaican social scientist at the University of the West Indies, was commissioned by the Jamaican government to conduct a study on the Rastafarian movement. His findings strongly augment Chevannes's thesis. "Jamaica's multi-racial nationalism which officially underpins and seeks to definitely describe the nation's groping identity met its fiercest and most positive antagonism from the black activist Rastafari movement. "12

The Rastafari movement challenged the lower class to look to itself to develop its own culture and to reject the notion that white is better. It is from this Black nationalism, inspired by the Rastafarian movement, that Jamaica's reggae music and culture emerged. Reggae music is a

form of folk art in the field of popular music. These are the singers who bespeak the tragedy and the pain, the hopes and the aspirations of the ghetto. In their music, the reggae, there is eloquently foreshadowed the concept of a just society as they protest its absence. ${ }^{3}$

'Ibid., 8.

${ }^{2}$ Nettleford, 41.

Michael Manley, The Politics of Change (London: André Deutsch, 1974), 156. 
Recognizing reggae music as a cultural change agent, the Michael Manley government of the 1970 s actively promoted and supported its development. ${ }^{1}$

Through this new music form, pride in Black ethnicity was promoted in the Jamaican psyche and the old institution was protested. The result is a generation of Jamaicans born with a new sense of ethnic pride and dignity.

The traditional stereotyping of Browns, Blacks, and Whites has been radically and perhaps permanently undermined. This new generation of Jamaicans does not compete on the criterion of color in order to attain as their predecessors did. ${ }^{2}$ The focus in contemporary Jamaica for social mobility is more economic than on skin color. But as Winton A. Thompson wrote, reggae music cannot be

\footnotetext{
'Michael Manley, Jamaica's Struggle in the Periphery (London: Writers and Readers Publishing Cooperative Society, 1982), 80 .

${ }^{2}$ This is not to be construed that the institutional perception has completely died out of the Jamaican psyche, there is still residue of it to be found. Kaplan argued in 1975: "There has been some alteration in class criteria and even more in class composition and mobility patterns, giving the appearance of greater fluidity throughout the system. But basically the factor used in ranking people has remained the same. Real change in ranking would involve abandonment of traditionally restrictive and white-oriented norms. . . It is not likely that this will occur in the foreseeable future" (Kaplan et al., 103). This statement was made in 1975, twenty years ago. Those then who depended on the basic "factor used in ranking people" are not the only ones dominant in the culture, their children have grown. The impending change that was embryonic in 1975 today has significantly matured. Kaplan was incorrect in his prophecy. There is significant and irreversible adjustment to the old classifications of people.
} 
appreciated or understood without "the main producers of the music, the Rastafarians."' And Barry Chevannes, in conducting his study of the Rastafarian movement in Jamaica in 1989, shows that the Rastafari movement has exorcised the ideology of racism in Jamaica. ${ }^{2}$

\section{Politics in the 1970 s}

In the 1970s, the Peoples' National Party (PNP) was responsible for the governance of Jamaica. During this period the Jamaican economy experienced negative growth. ${ }^{3}$ This period also saw a rise in class and racial militancy.

Violent crimes escalated in the power contention between the JLP and the PNP. Organized gangs engaged in orgies of excessively violent crime against the middle class and the rich, who became victims of rapes, robberies and beatings that seemed designed to settle scores with the privileged class and ethnic groups.4

"During this period many among the dominant ethnic 'minorities' exported capital, closed down enterprises and migrated in large numbers to the USA and Canada."5 A vacuum was created and later became occupied by Blacks in the business sector. Blacks bought out firms sold by fleeing owners. Others took advantage of market opportunities and

'Thompson, 263 .

'See Chevannes, The Case of Jah vs. Middle Class Society: Rastafari Exorcism of the Ideology of Racism in Jamaica.

\footnotetext{
${ }^{3}$ Kaplan et al., 104.

${ }^{4}$ Lewis, 253 .

${ }^{\text {sIbid. , } 255 .}$
} 
began investing. Many started new enterprises to provide and capitalize on needs created in the economy.

Economic Conditions

Lynette Joseph, writing on the Jamaican middle class, stated, "In Jamaica today, one can identify at least two routes to achieving middle class status. One is achieved through access to social resources, . . the other is achieved by amassing income through entrepreneurial activity."1

The government's fiscal policies contributed to the adjustment in the traditional class structure. The structural adjustment policies that were imposed on the country by the government resulted in altering the relative balance between bureaucratic and salaried professionals. Professionals and White-collar workers have come to the realization that status in the form of educational classification is no longer adequate to maintain their place and class in the society. ${ }^{2}$

Many within the traditional class who were dependent on their income to afford their middle-class status and lifestyle eventually lost this status. Some, even within

'Lynette Joseph and Derek Gordon, The Middle Class in Jamaica: A Quantitative and Qualitative study of the Characteristics of Its Members, Changes in Their composition and Strategies Adopted to Deal with the Economic Crisis (Kingston, Jamaica: Documentation and Data Center, University of the West Indies), 1, 13.

${ }^{2}$ Ibid., 16. 
the lowest income group, created new entrepreneurial activities to meet the financial challenges brought about by the government policies. New businesses began emerging such as auto parts dealers, building contractors, minibus owners, custom brokers, bakery owners, fast-food operators, computer distributors, and boutique owners.' The income generated by many among these traditional lower-income groups resulted in the ability to earn income exceeding the income of many in the traditional middle class.

The Middle-Upper and Upper Classes: Values and Concerns

The upper class in most societies is usually quite small, "about 3 to 4 percent of the population." ${ }^{3}$ The same is true of the upper classes in Jamaica. ${ }^{4}$ Irrespective of their limited numbers, they

consist of the richest and most powerful people in the community. Often their wealth has been in the family for several generations and this continuity in combination with economic resources confers considerable power. At the national level, the upper class has had great influence on domestic policy and foreign affairs. Most members of the upper class are highly educated, many having attended elite colleges and universities. ${ }^{5}$

${ }^{1}$ Ibid., 17.

${ }^{2}$ Norman Goodman, Introduction to Sociology (New York: Harper Perennial Publishers, 1992), 132.

\footnotetext{
${ }^{3}$ Ibid.

${ }^{4}$ Stone, 37 .

SIbid.
} 
Societies are normally divided into three major classes--upper class, middle class, and lower class'--but sociologists have found it necessary to create further subdivisions. These subdivisions range "from upper upper to lower lower"'2 classes.

What are their concerns, interests, and values? According to Smelser, the only difference between the upperupper class and the lower-upper class is family background. The lower-upper class enjoys almost the same lifestyle as the upper-upper class, but does not have the same aristocratic background. ${ }^{3}$ The upper-middle class of most societies consists mainly of business and professional persons with high incomes." They are the "doctors, lawyers, business owners."5 In Jamaica, many within the upper-middle class are involved in these traditional professions, while those within the upper-upper class "are a part of the entrepreneurial elite and have extensive business concerns, such as banking, import-export, or natural resources exploitation." 6

\footnotetext{
${ }^{1}$ Miller, 271.

${ }^{2} \mathrm{Neil} J$. Smelser, Sociology (Englewood Cliffs, NJ: Prentice-Hall, 1981), 199 .

${ }^{3}$ Ibid.

${ }^{4}$ Goodman, 133 .

s'smelser, 199.

${ }^{6}$ Kaplan et al., 104 .
} 
Education

Both the upper-middle and upper classes share very similar values. The reason for this is that the uppermiddle class view the upper class as the standard to be reached. 1

One of the primary interests of both groups is education. Many high schools in Jamaica were built by monies from the upper class. ${ }^{2}$ However, the upper class have a "traditional practice of sending their children abroad" 3 for their education. The middle class seek education for their children to confirm their middle class status. 4

\section{Money}

Social advancement is very important to the uppermiddle class. Their desire is to imitate the tastes of the upper class. The acquisition of the accoutrements valued by the upper class is of prime concern to them. ${ }^{5}$ This group of people will bend their energies in pursuit of wealth.6

Money is also very important to the upper class. Their wealth is tied up in investments, hence, "whenever the

\footnotetext{
${ }^{1}$ Ibid.

'Miller, 272 .

${ }^{3}$ Ibid. , 273.

${ }^{4}$ Ibid. , 271.

${ }^{\text {s} K a p l a n ~ e t ~ a l ., ~} 105$.

${ }^{6}$ Ibid.
} 
wheels of . . commerce are turning, these people are making money. As long as capitalism survives, these people survive." 1

\section{Family}

Claerbaut writes, "Relatively little is known about the upper classes because they have a thirst for privacy and so escape the usual data-gathering by sociologists."2 Irrespective of their closed society, certain traits characterize the upper classes. Family reputation appears to be very important. "The upper class is identified by families and it is the family name that must be advanced and protected at all costs." ${ }^{3}$ Expenditures often are made to magnify and elevate the family name." "Many upper-class families, for example, have foundations bearing the family name, and upper class individuals frequently lend themselves (and their names) as chairpersons of charity drives and socially respectable fund-raising efforts."'s Some outstanding names in Jamaica are the Issers, Geddes, and the Matthelons. It is argued that there are approximately seven

\footnotetext{
${ }^{1}$ Claerbaut, 54 .

'2Ibid., 53 .

${ }^{3}$ Ibid.

${ }^{4}$ Ibid.

${ }^{5}$ Ibid.
} 
to ten family names that "run' Jamaica and you will be lucky to have their last name."

The middle class, on the other hand, are still in pursuit of this level of recognition. Their family name is still being built. Family is just as important to them. Without the tradition of family name the upper-middle class seeks name recognition and social respectability by being involved in the community. Their "thirst for respectability is probably the most intense among the strata."2

\section{Ethnic Nationalism}

Ethnic nationalism is not so much a concern or value of the upper class as it is for the upper-middle class. Barry Chevannes sees "middle class nationalism as a major factor that led to the formation of the Peoples' National Party (PṆP) in 1938."13 This nationalism finds expression in politics. The middle class in the 1980 s argued with the government for relying too heavily "on foreign and local white consultants and advisors." 4 In March 1898, when the newly elected PNP government appointed some local white advisors, it sparked strong public controversy from the

\footnotetext{
"The Jamaican Rich" [unofficial Jamaican Website] (accessed August 2, 1996); available from http: www/hway / net/xam/risto.htm.

${ }^{2}$ Ibid., 54

${ }^{3}$ Chevannes, 14 .

${ }^{4}$ Ibid. , 23, 24 .
} 
middle class. Many voiced concern that appointments by the government revealed yet again a lack of confidence in the ability of Blacks, "at a time when they manifested equal if not greater competence and loyalty to the country."1

\section{Violence}

The middle and the upper class share concern for the violence in society. Not unlike the upper classes, the upper middle class holds the lower class in suspicion. ${ }^{2}$ Most of Jamaican politicians are mainly from among the middle class. They gain economic support, personal distinction, and advancement through participation in politics. ${ }^{3}$ This is an achievement they could not have made without the masses. ${ }^{4}$ Surprisingly, while this group strives to gain political control, they also appear to bend all energies to deny the sentiments, desires, and ambitions of the masses. They assume that the masses are too prone to violence and that crime is largely perpetuated by the masses.

'Ibid.

${ }^{2}$ Kaplan et al., 106.

${ }^{3}$ Ibid.

${ }^{4}$ Ibid.

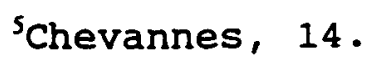




\section{Community Involvement}

It has been discovered that the upper class lends its name, influence, and money to various community projects. They have been involved in the building of schools and various other community building activities.' The uppermiddle class, on the other hand, seeks social recognition and respectability by being involved in various community affairs. It is not unusual to see both groups coming together to discuss "strategies to improve and enhance the services they deliver at the community level. Jamaica has had a long tradition of community development initiatives."2

\section{Religion and Church}

It is popular to view the upper class as belonging to the traditional churches, such as Anglican, Catholic, and Presbyterian. However, interviews with some leading administrative representatives of these traditional churches conducted for this study resulted in a fascinating revelation. When the administrative representative of the Anglican Church was queried concerning the upper class who were members within the Anglican congregation, his response was that this class was not to be found in the Anglican Church. His view was that the upper class are predominantly

${ }^{1}$ Patrick B. Bryan, Philanthropy and Social Welfare in Jamaica (Kingston, Jamaica: Institute of Social \& Economic Research, 1990), 3 .

${ }^{2}$ Rosemarie stone, The Stone columns (Kingston, Jamaica: Sangsters Book Stores, 1994), 21. 
members of the Catholic Church.' This view was also shared by the representative of the Baptist Church.

Subsequent interviews with the immediate past Archbishop of the Catholic Church of Jamaica brought out another interesting discovery. The Catholic leader expressed surprise. He said that he was aware of the perception, but stated that it was faulty. ${ }^{2}$ The archbishop assumes that what could have contributed to this perception is that many state functions are held in catholic and sometimes Anglican churches. The upper class are regularly in attendance and these are highly publicized events. Repeated occurrences would give the impression to the public that the upper class are members of the Catholic and Anglican churches.

It is my conclusion that members of the upper-class community in Jamaica are, for the most part, unchurched. "They tend to manifest the religious agnosticism of modern Europe, as well as the operational faith in science and administration. " 3

In contrast, the middle class is more committed to traditional Christianity than the upper class. "Their fundamentalist Christianity is based on the belief in an

\footnotetext{
'Ernley Gordon, interview by author, February 1996.

${ }^{2}$ Samuel Carter, interview by author, February 1996.

${ }^{3}$ Kaplan et al., 104.
} 
omnipotent Christian God whose actions are morally perfect and who can be appealed to but not manipulated."1

In worship form, members of the upper-middle class, not unlike those within the upper classes, who attend church, incline towards churches that have religious practices close to those of the European sister churches such as Anglican, Presbyterian and Roman Catholic. ${ }^{2}$

It was discovered that the upper class, for the most part, do not attend church and the middle class inclines towards the traditional churches. What is the relation of these groups to the Seventh-day Adventist Church in Jamaica? Is the church reading this group? What impact is it making? What social classes comprise the Seventh-day Adventist church membership? These are some of the questions the study now attempts to explore. It is necessary to look at the Seventh-day Adventist Church contextually and to view its growth and development in order to attempt a discussion of these issues.
'Ibid., 107.
${ }^{2}$ Ibid., vii. 
CHAPTER 3

\section{THE SEVENTH-DAY ADVENTIST CHURCH}

AND THE SOCIAL CLASSES

This chapter looks briefly at the growth and development of the Seventh-day Adventist Church in Jamaica, its success in evangelism, and the classes being reached by its message.

The Seventh-day Adventist Church in Jamaica: origin, Growth and Impact

$$
\text { origin }
$$

The Seventh-day Adventist Church in Jamaica was organized in 1903. Jamaica's population in those early years was 756,000 . The church was organized with the membership ranging between $1,188-1,200,1$ seventeen churches, three ordained ministers, and four ministerial licentiates. The appellation given to it was West Indian Mission. By 1995 the church had matured into three organized conferences, 535 churches, ninety-three ordained ministers, one hospital, four clinics, eight high schools, and one

'Nominal difference between the figures given in the SDA Yearbook (Washington, DC: General Conference of SDA, 1903), 74 and the SDA Encyclopedia (Washington, DC: Review and Herald Publishing Association, 1976), 696. 
senior liberal arts college. ${ }^{1}$ Jamaica's population in 1995 was 2,500,000 and the Seventh-day Adventist church membership was 162,831 .

The Seventh-day Adventist church did not begin in Jamaica as a result of an evangelistic campaign or church planting. In 1889 , a colporteur named William Arnold came from North America to the West Indian island of Antigua. There he sold a book to a man who sent it to his son, James Palmer, in Jamaica. Palmer, in correspondence with the SDA International Tract Society, soon arranged to have SDA publications sent regularly to the island. One of the publications was read by an influential English woman, by the name of Margaret Harrison, who was living on the island. She eventually became interested, influenced five other families and they became the first Sabbath-keeping company in Jamaica.

In 1893 Mrs. Harrison visited Battle Creek for medical treatment. During her visit, while the General Conference was in session, she appealed to the leaders to send a missionary to Jamaica. In a positive response to her request, A. J. Haysmer and his family became the first official missionaries to Jamaica. The following year, 1894, the first SDA church on the island was organized with

\footnotetext{
'Seventh-day Adventist Yearbook (1995), 192-195.
} 
thirty-seven members with membership increasing to 102 by $1895 .^{1}$

Several factors contributed to this rapid growth in membership. The church members became very proactive in circulating SDA publications throughout the island. They also lent or gave away large numbers of signs of the Times, tracts, and pamphlets. Many of the young men and women who became Adventists in these early years trained as colporteurs and sold SDA books in every parish. As a result of this aggressive promotion of the church's teaching, the membership increased to 300 in $1896 .^{2}$ In a mere four years after the introduction of the SDA message in Jamaica, "the first general meeting of workers for the West Indies was held in Kingston (Nov. 5-15, 1897). The West Indian Mission was organized with its headquarters in Jamaica" ${ }^{3}$ in 1903.

In the ninety-three years of its existence, the growth rate of the Seventh-day Adventist Church in Jamaica has been remarkable. The ratio of SDAs to the Jamaican population in 1903 was $1: 630$. In 1995 the ratio was $1: 15$.

The rapid growth of the SDA movement can also be seen in the development of three conferences on an island that is a mere 145 miles long by 51 miles wide:

1. 1903; Jamaica Conference formed

'SDA Encyclopedia (1976), s.v. "Jamaica," 697.

${ }^{2}$ Ibid.

${ }^{3}$ Ibid. 
2. 1944 ; Conference divided into East Jamaica Conference and West Jamaica Conference

3. 1962; Conferences further divided with Central Jamaica Conference organized.

With 1:15 Jamaicans in 1995 laying claim to the Seventh-day Adventist faith the question that is relevant to this study is, What percentage of SDAs are members of the middle and upper classes? Are the upper-middle and upper classes responding to the SDA message?

\section{Which Classes Are Being Reached?}

This study has revealed that there are three major classifications for people in Jamaica, the lower class, the middle class, and the upper class.' Social scientists have made it very clear that these classes can be identified traditionally along the color line: Blacks, Browns, Whites. ${ }^{2}$ Traditionally, those within the upper class, for the most part, have been labeled agnostics in regard to religion. They are not really committed to any church group. The few who at times attend church are found mostly in the traditional churches such as Anglican, Presbyterian, and Catholic. Within the middle-class community a higher percentage are committed Christians attending churches that are predominantly of Protestant persuasions. ${ }^{3}$

\footnotetext{
'Manley, The Politics of change, 57.

${ }^{2}$ Carl stone, 7 .

${ }^{3}$ Kaplan et al., viii.
} 
Attempts to evenly divide the classes into three distinct, clearly defined groups, as so far has been the practice, can lead to the creation of a misleading perception. Within each class there are hierarchical lines as well, separating and categorizing people according to wealth, income, education, influence, economics, among other factors. This has led to a three-tiered system further developed within each class.

For example, within the lower class, there are labels such as the upper-lower, the middle-lower, and the lowerlower. Many within the inner-city ghetto culture could be said to belong to the lower lower.' Concerning the middle class (traditionally the Browns), the three-tiered system is also operative. There are the lower-middle, the middlemiddle, and the upper-middle. And the same is true of the upper class. The point is, within each class, there are informal indexes such as education, influence, societal positions, material accoutrements, financial acquisitions, color, and status that are used to categorize people. ${ }^{2}$ When interviewed concerning the composition of the membership of the SDA church, leaders on the island responded that the upper classes are not generally present

'While no documented evidence was found to verify this for bibliographic purposes, as one who grew up in the Jamaican situation, this is a popular perception.

${ }^{2}$ It is necessary to be informed understanding these perceptions and categorizations to intelligently discuss the issue concerning those who are not being reached by the SDA message. 
among the SDA membership.' In 1996, the secretary of the Central Jamaica Conference, in discussing this dissertation, pointed out that the SDA membership is not generally to be found among the upper classes. ${ }^{2}$ There are a few isolated individuals from the upper classes in the church but they are numerically insignificant.

The Seventh-day Adventist church membership is largely composed of those from the middle-middle, the lower-middle, and the poor. It is my experience, after having pastored on the island, that no major denomination is reaching either the very rich or the very, very poor. Efforts are made by one or two Catholic movements to reach the inner-city ghetto culture (Richard Holong and Father Albert), and one noticeable Protestant group (Herro Blair's Deliverance Center with its soup kitchen), but predominantly the very poor within the inner city incline towards Rastafarianism or the reggae culture.

A quick visual survey of the island's 535 SDA churches will also support the fact that few upper-class people attend the SDA church. Within the cities and principal towns such as Spanish Town, May Pen, Mandeville, Ochio Rios, Montego Bay, and Kingston can be found the middle-middle,

\footnotetext{
'Interviews conducted in February 1996 with all the main SDA leaders on the island brought out the common view that the SDA church is not reaching the upper class.

${ }^{2}$ Everette Brown, interview by author, February 1996.
} 
lower-middle, and the poor, along with a few upper-middle, attending SDA churches.

The SDA church is made up largely of the working class. A generous proportion of the lower-middle, middle-middle, with a very limited group from the upper-middle, are members of the church.

Who is reaching the upper classes? If the SDA church is not reaching the upper classes, which church group is reaching them? The Catholics argue it is the Anglicans, the Anglicans argue it is the Catholics. It is apparent that no group has been strategizing to evangelize the upper classes.

Ernley Gordon, the Anglican representative and a principal religious writer in the island's leading newspaper, said that there has never been, in the history of the church in Jamaica, a mission to the upper class. ${ }^{1}$

Why the Seventh-day Adventist Church

Is Not Reaching the Upper classes

The SDA church in Jamaica has been experiencing phenomenal growth and expansion. This has been historically due to the efforts of the lay people and the clergy. In Jamaica today approximately one in fifteen Jamaicans is an Adventist. The Jamaican population is 2,500,000. The SDA membership is 162,831 . There are 2,337,169 Jamaicans still to be reached by the SDA message. Among this group are members of the upper-middle and upper class.

\footnotetext{
'Gordon interview, February 1996.
} 
The Seventh-day Adventist Church has been organized on the island of Jamaica for ninety-three years. The church is now an established institution in Jamaican life. Commenting on the Seventh-day Adventist presence and contribution, Samuel Carter, the former archbishop of Jamaica said, The Seventh-day Adventist Church, especially in the areas of education and health, has been making significant contributions to the life of the nation. What impresses me most are your doctors who pray with members of my church when they are hospitalized in your institution. Please continue. And when it comes to an excellent work ethic, and honesty, most institutions have no reservation in employing seventh-day Adventists. ${ }^{1}$

Since the inception of the church, baptisms have steadily increased. With the organization of the three conferences on the island the number of baptisms has accelerated. However, the large number of baptisms into the Seventh-day Adventist Church have been predominantly from among the lower-income groups. Conversions from among the high classes have been almost negligible.

Why has it been difficult for the SDA Church to evangelize the secular rich in Jamaica? What are the barriers? This study suggests that there are at least seven categories of barriers that work against the church effectively reaching the upper classes. The seven categories can be labeled: (1) historical factors, perception, (3) secularization, (4) institutional evangelistic practices, (5) Seventh-day Adventist lifestyle

'Carter interview, February 1996. 
and culture, (6) theological distinctives, and (7) materialism.

\section{Historical Factors}

Chapter 1 established that the larger percentage of the upper classes who attend church are most likely to attend churches that are called the traditional churches. Part of the reason for this practice can possibly be found in the comment of the president of the west Indies Union, Silas McKinney. He states that the tendencies among these classes is to view non-traditional churches as sects. ${ }^{1}$

Pastor K. G. Vaz, who has worked extensively and successfully in the Jamaican community for over forty years as pastor, evangelist, college president, union secretary, and chairman of the Religion Department of West Indies College, argues that many families among the rich have traditionally held membership within the traditional churches. ${ }^{2}$

Traditional churches in their earliest history in Jamaica were firmly established within the general community. When those churches first arrived on the island, White plantation owners ${ }^{3}$ known as the planter class, who

\footnotetext{
'President Silas Mckinney, interview by author, February 1996.

${ }^{2}$ Pastor K. G. Vaz, interview by author, February 1996.

${ }^{3}$ Eric Williams, The Negro in the Caribbean (Westport, CT: Negro Universities Press, 1969), 57.
} 
were virtually in charge of the country, maneuvered the churches into the position where the churches would serve their interests. The main source of revenue in Jamaica was sugar and the plantations were dependent on slave labor.'

The planter class became nominal members of the incoming churches, which cooperated with them and supported their interests. These churches were supported and funded by them. other churches that refused to cooperate with the planter class met with vicious resistance. ${ }^{2}$

For instance, about 1801 the Reverend Colin Donaldson, Rector of St. Mary, strongly opposed slavery. . . . His criticism . . . cost him $\$ 1,400$ damages in legal action for defamation of character. In 1812 he was imprisoned for three months for slandering the custos of the parish. The point is that the planters dominated the society; they had friends in all the powerful institutions of the island, and so it was difficult to oppose them. ${ }^{3}$

This cooperation by the churchmen with the planter class did not result in mass conversion among the rich upper class. The Rector of st. Ann described the situation in Jamaica as "pitiful and hopeless, empty churches."4 But the privileged community of the upper class built churches and even attended them, but there was no mass conversion. These activities between the church and the secular rich who

\footnotetext{
'Eric Williams, Capitalism and Slavery (New York: Capricorn Books, 1966), 29.

${ }^{2}$ Edmund Davis, Roots and Blossoms (Barbados: Cedar Press, 1977), 7 .

${ }^{3}$ Ibid. , 9.

${ }^{4}$ Ibid., 8 .
} 
controlled the community resulted, eventually, in the churches being viewed as the property of the state.

Clergymen were selected by the custos ${ }^{1}$ or by the governor, and the state paid their salaries. ${ }^{2}$ The upper class came to see these churches as their own. Davis, commenting on this issue, labeled those in the planter class, who only funded and supported churches which cooperated with their interests and attended them, as "secular Christians." 3 The churches supported and lent their influence to the planters' interests, but the planter class were not practicing Christians or committed to the ethics of scripture. They attended and then returned to their usual activities and lifestyle.

This cooperation between the established church and the upper class led to the perception among the local community that

God was a foreigner--the God of the white, the rich, and the oppressor. He did not reflect their cultural and native experience. He was an outsider who was unconcerned about their sufferings under Western imperialism. ${ }^{4}$

'Custos is an official guardian or caretaker of a town, selected by the government.

${ }^{2}$ Davis, 6-8.

${ }^{3}$ Ibid. , 7 .

${ }^{4}$ Ibid., 10. 
The church in this early period went as far as to promote the felt interests of the White planter class. The church allowed its

preaching, politics, and practices to be molded by those persons at the top of the social pyramid. In the interest of the plantocracy they preached to the slaves a gospel of submission and a futuristic eschatology which was unrelated to the brutality and violence of the society. For instance, in 1739 count $z$ inzendorf, the Moravian leader, counselled the slaves in St. Thomas that God punished the first Negroes by making them slaves, and that their conversion to Christianity would make them free but not from the control of their masters but from their wicked habits and thoughts and everything that made them dissatisfied with their lot. ${ }^{1}$

In succeeding generations, some of these traditional churches protested the evil of slavery. This protestation led to a decline of support and attendance from among the upper class. ${ }^{2}$ New missionary movements such as the Baptists and Methodists arrived in the island and focused their evangelism towards the slaves and the lower class. The planter class took the position that these new missionary movements were a threat to the "status quo" ${ }^{3}$ and held these new missionary movements in suspicion. Not only was there a decline in support by the upper classes for some of the traditional churches which were protesting slavery, but almost a wholesale absence of membership from among these new non-traditional churches. The churches who retained the

\footnotetext{
'Ibid. , 8, 9.

${ }^{2}$ Gordon interview, February 1996.

${ }^{3}$ Davis, 10.
} 
upper-class membership and support, in many cases, were churches that promoted their interest.

\section{Perception}

Another factor that forms a barrier which militates against the SDA Church reaching the upper classes can be categorized as a perception problem. In contemporary Jamaica, the membership of most non-traditional churches is composed primarily of those from the lower classes. This perhaps explains why these churches focus their interests, vocabulary, concerns, issues, and theology in ways relevant to the lower-income group. Aggrey Brown, discussing this issue, argues that non-traditional churches too often carry the perception that they are inferior to the upper classes and by the same token this class is superior to them. ${ }^{1}$ This perception has contributed to the alienation between the two classes. Each class seems to perfer to mind its own business. ${ }^{2}$

The average non-traditional churches do not design their evangelism to reach the upper class. They are content to work with those within their own class. Non-traditional churches had their origin among the "ignorant" lower class and have historically remained in that group. ${ }^{3}$

\footnotetext{
'Aggrey Brown, Color, Class and Politics in Jamaica

(New Brunswick, NJ: Transaction Books, 1979), 1.

${ }^{2}$ Ibid.

${ }^{3}$ Ibid.
} 
Perception is not only a problem on the part of the non-traditional, lower-class church community. Among the upper classes, there is the perception that those who do not belong to the traditional churches are less educated and incapable of appreciating the high church liturgy practiced in these churches.'

It is not to be construed that in Jamaica today the non-traditional churches are totally devoid of the middle and upper classes. As has been demonstrated in chapter 1, there are people who are lower class in status who have moved into the higher class. In doing so, they have kept their religion. This means that many non-traditional churches today enjoy members who can be categorized as upper class. This is what Donald McGavran refers to as "lift."

The founding mission or church establishes schools, hospitals, agricultural centers, literacy classes and many other institutions to serve and help the general public and especially the new brothers and sisters in Christ. If they are illiterate, they are taught to read. Their children, attending church and mission schools--or, increasingly, tax-supported schools-become grade-schools, high schools, and college graduates. Perhaps they go to Christian vocational schools and become mechanics, radio technicians, or artisans. Perhaps, sent to nurses' or teacher training schools, they are snapped up by the rapidly expanding government health and educational programs and get good salaries. Able men and women rise to positions of international note in the churches. . . The wealth of Christians rises. They become middle-class people. . . All this I am calling "lift."2

'Ibid.

${ }^{2}$ McGavran, Understanding Church Growth, 211. 
This progression in status has not significantly affected the perception, however. This is partly due to the fact that members within the non-traditional church who have moved into upper-class status are too few to make a shift in the general perception.

The Seventh-day Adventist Church being a nontraditional church with its membership largely from among the lower classes is caught in this perception. The higher classes are slow to shift their perception; they view membership in the Seventh-day Adventist Church as they do most traditional churches. They hold the view that SDA church members are odd, less educated, less cultured, and should be avoided. Mckinney said this could be due to the "cultphobia"l that exists with some among this group.

The perception held by many in the upper classes is that the SDA church is a cult or at best a sect. The awareness of this perception is confirmed by Pastor Kenneth G. $\operatorname{Vaz}^{2}$ A significant contributing factor to this perception could be due to a lack of experience to the teachings of the church. ${ }^{3}$ The Jamaican community resident

${ }^{1}$ Mckinney interview, February 1996.

${ }^{2} \mathrm{Vaz}$ interview, February 1996.

${ }^{3}$ In my pastoral experience in Jamaica, whenever I came into contact with people within the upper classes they were always surprised to learn that there is more to the SDA church than worshipping on Saturday and not eating pork. 
in the higher classes appears not to be informed or intelligent to the beliefs and practices of the church. ${ }^{1}$

Perception is not only a problem of the upper class. Members in non-traditional churches are also handicapped by their perception of the upper class. They are inclined to view the upper classes as materialistic and as not being interested in spiritual things. ${ }^{2}$

The interviews I conducted reveal a common complaint. Religious non-SDA leaders complain that the SDA church conducts its affairs in a manner that insulates it from the general community. Basil Reid, president of the West Jamaica Conference of SDAs, agrees with this view but responds to the complaint in the following manner: "The church did not create this insularity."3

${ }^{1}$ This should not be surprising. According to George Hunter in his book How to Reach Secular People (Nashville: Abingdon Press, 1992), a common myth held by most churches is to assume that folks in the secular community are religiously literate. Hunter says it is a myth to assume that secular people are philosophically sophisticated geniuses who have read Christian literature from Augustine to Zwingli, and rejected the christian case in toto on rational grounds. (43)

${ }^{2}$ George G. Hunter argues that this perception is a myth. He writes that secular people "report in church preference surveys, the same religious affiliation as did their parents, and they participate in the traditional rites of passage but they attend Sunday services less often" (43). Lee Strobel argues in chapter 2, "Understanding Your Unchurched Friends," that rejection of the church by this group doesn't mean that they reject God. Inside the Mind of Unchurched Harry and Sally (Grand Rapids, MI: Zondervan Publishing House, 1993), 45 .

${ }^{3}$ Basil Reid, interview by author, February 1996. 
Pastor Bennett, president of the West Jamaica Conference, argues that "the church needs to create initiatives to reach out to the secular community. This would dissolve the perception of insularity."I In other words, initiatives on the part of the church to deliberately reach out to the secular rich $^{2}$ in meaningful ways could result in educating the misperceptions that some within this community hold regarding the church.

\section{Secularization}

Another major barrier that prevents the church from reaching this community is secularization. The upper classes, for the most part, are secularized. Western culture is increasingly moving towards secularization. It is not necessarily a conscious, deliberate choice on the part of society, but various factors have been developing that have resulted in secularization becoming a part of the natural progression of contemporary culture. Jon Paulien, in the book present Truths in the Real world, ${ }^{3}$ discusses some of the factors that contribute to a society becoming secular. Paulien states that secularization occurs when

a society is becoming more and more inclined to view life without reference to God or religion. . . .

'J. G. Bennett, interview by author, February 1996.

${ }^{2}$ The term secular rich is used interchangeably with upper-middle and upper class.

${ }^{3}$ See chapter 4 of Jon Paulien's present Truths in the Real World (Boise, ID: Pacific Press Pub. Assn., 1993). 
Religious values and practices are increasingly discarded. And the church as an institution declines in influence on the larger society. A secular person or society may not consciously reject religion or God, but God plays a diminishing role in people's day to day lives.'

George Hunter augments Paulien's view. He writes that secularization may be defined as

the withdrawal of whole areas of life, thought, and activity from the control or influence of the church. The church experienced lost influence in every area of Western society's life--from education to government, economics, art, architecture, music, personal morality, and community life. ${ }^{2}$

Hunter further argues that secularization is not a phenomenon confined to the United States; it has influenced the entire Western culture. ${ }^{3}$

Paulien asks the question, "What kinds of people become secular?" And he answers by suggesting that people who live in cities, people with more education, young people, people who travel a lot, male more than female, people who are constantly in the public's eye, people who work in factories, people who work in the information industries,

'Ibid., 8.

${ }^{2}$ Hunter, 25, 26 .

${ }^{3}$ In presenting the facts, Hunter reveals in this book that the percentage of people attending church on an average Sunday has declined to $6 \%$ in West Germany and Italy, 1-3\% in Scandinavian countries, $12 \%$ in Great Britain, in Canada half of what it was 40 years ago, Australia less than half what it was 25 years ago. In the United States there are at least 120 million functional undiscipled people (14 years and older) $(24,25)$. 
and the rich are more likely to become secular than the poor. ${ }^{1}$

What does secularization in the West and, in particular, the United States have to do with the uppermiddle and upper class in Jamaica? Jamaica is a developing nation, centrally a part of the Western world, located in close proximity to the United States, poignantly influenced by Hollywood and the secularism that flourishes in the United States. Jamaicans visit the United States every weekend for shopping, sightseeing, and to socialize with friends. ${ }^{2}$ Those within the upper class and middle-upper class educate their children in U.S. universities. This group also visits the United States for medical care and other amenities.

Examination of Paulien's classification of those more likely to become secular shows that the Jamaican uppermiddle and upper class are situated squarely within his definition.

There is virtually no dissimilarity between Jamaicans of the upper-middle and upper class and their American counterparts. Even the stratifications among the classes are the same. David claerbaut, in analyzing the American social class system, suggested six sectors in which these

'Paulien, 49-51.

"The Jamaican Rich" [Unofficial Jamaican Website]. 
are to be examined--"upper-upper, lower-upper, upper middle, lower middle, upper-lower, and lower-low."'

Claerbaut argues that the upper-upper class is often referred to as "old money." There are those who have possessed truly super riches over a number of generations.2 The lower-upper class, called new money, differ from those in the previous category only in the length of time they have had their money. The dominance and influence of the upper-middle class on the community cannot be underestimated. Their moral values are dominant in the community, they take the lead in civic affairs, including education, it is their clothing style and social dimension that is taught as "proper" in most public schools, "it is imperative that those who wish to succeed in the American mainstream be able to communicate with members of this class." ${ }^{3}$

The factors that affect the upper-middle and upperclass community in the United States affect their counterparts in other Western countries. Secularization is one of those factors. Discussions in many cases relevant to the American secular community are applicable to the

\section{'Claerbaut, 53.}

${ }^{2}$ Ibid.

3Ibid., 54. (For a complete discussion on the upper class, the upper-middle class, and the rest of the classes from the American perspective, see pp. 53, 54 of Claerbaut's book.) 
Jamaican secular community. Secularization is a barrier which prohibits the SDA church from making progress among the secular rich. Secularization results in secular people becoming

almost totally insulated from Christianity. They don't read their Bibles or listen to sermons. They don't read tracts that someone may press into their hands. - . The reality is that secular people--perhaps $70 \%$ of Americans--are almost insulated from everything that we consider normal. . . . The typical Adventist worship service is not attractive to secular people.'

Among the upper class and middle-upper class there are people who conduct their lives outside of the influence or worldview of the Christian church. This is not to say that these people are hostile to religion or God.

George Hunter presents three myths that are popularly held by the church and the wider community towards secular people:

(1) Secularization has erased all religious consciousness from people's minds; (2) secularization has erased moral consciousness; (3) all secular people are philosophically sophisticated geniuses who have read Christian literature from Augustine to $2 w i n g l i$ and rejected the Christian case in toto on rational grounds. The vast majority of secular people are not epistemologically sophisticated; most are naive, superficial, gullible people who may fall for anything. ${ }^{2}$

Lee Strobel augments Hunter's findings. In chapters 4 and 5 of his book, Inside the Mind of Unchurched Harry and Mary, he provides fifteen characteristics that one must be

\footnotetext{
'Paulien, 41, 42 .

${ }^{2}$ Hunter, 42,43 .
} 
conversant with in order to acquire an understanding of the secular culture. Interestingly, these characteristics reveal that members of the secular culture, if properly understood and intentionally worked with, might be reached with the gospel.'

Hunter argues that the church's responses to the secular community have traditionally resulted in alienating this group. ${ }^{2}$ In order to be effective, the church has to carefully design its evangelism to reach these upper classes.

\section{Institutional Evangelistic Practice}

Possibly the greatest barrier preventing the seventhday Adventist Church from being more effective in reaching the higher classes within the community with the gospel is resident within the institution itself, the methodology used in the church's evangelism.

The conferences in Jamaica are successful in converting large sections of the Jamaican population to the SDA faith. In 1995 6,980 individuals were baptized. The breakdown is as follows: Central Jamaica Conference, 2,892; East Jamaica Conference, 1,790; West Jamaica Conference, 2,288.3

'It will call for a paradigm change in evangelistic models and forms that have traditionally been used in the evangelization of the secular community.

${ }^{2}$ Ibid. , 29.

${ }^{3}$ SDA Yearbook (1996), 192-195. 
When asked how many of these baptisms were from among the middle and upper classes, Silas Mckinney, president of the West Indies Union, said they were too few to mention.'

West Jamaica's president concurred with the other conference presidents, reporting that the baptisms are largely from among the masses. The Central Jamaica Conference president informed me that the upper class in the church within the conference is very few. The West Jamaica Conference president stated that there might be just two or perhaps three very wealthy members within the West Conference membership of 46,372 .

"We are not reaching the upper classes"2; perhaps "no religious body in Jamaica is reaching this group. "3 ${ }^{3}$ This is the consensus among the church leadership in Jamaica. But what is the problem? Why, in spite of effectiveness in reaching the poor, are the evangelistic strategies used by the church in Jamaica not effective in reaching the wealthier classes?

When the aforementioned questions were put to the church leaders, one of the common responses given refers to how evangelism is conducted in Jamaica. ${ }^{4}$ Evangelism in

'Mckinney interview, February 1996.

${ }^{2}$ Reid interview, February 1996.

${ }^{3} \mathrm{Vaz}$ interview, February 1996.

${ }^{4}$ This was the voiced consensus of all the leaders who were interviewed. 
Jamaica is normally conducted under tents. Tent evangelism is very effective in reaching the masses who are predominantly the members of the lower class.

How is tent evangelism conducted? The tents are placed on open, generally unpaved commons, chairs are placed on the ground, and the evangelist preaches for four to six weeks. At the end of an average evangelistic series one to three hundred people are baptized. ${ }^{1}$

The church leadership argues that due to their lifestyle and culture, the upper classes do not attend and are not influenced by tent evangelism.

Acting chairman of West Indies College Religion Department, Pastor K. G. Vaz, suggests that new strategies in evangelism are needed to reach the secular rich. ${ }^{2}$ when interviewed on this point, the presidential leadership of the SDA church in Jamaica agrees.

With this agreement among the general leadership, I asked why the study of a strategy should not been pursued in order to reach the higher class? The responses from the leaders were instructive.

(EJC) president responded with the following:

The problem with implementing a method to reach this class lies in how we as a church promote and recognize success. Our promotion and recognition of success

${ }^{1}$ During my tenure in pastoral ministry in Jamaica, this was the average. An analysis of the conference's yearly report sheets confirm this average.

${ }^{2} \mathrm{Vaz}$ interview, February 1996. 
militate against reaching the upper class. We have a number syndrome. Evangelists (local and overseas) want to be placed in populated areas where they will be quaranteed success. Consequently, they seek the masses. They need large numbers.i

The Union president states:

If someone should target this group, soon the individual would be viewed as a failure; his job might be in jeopardy and no conference might want to call him. If one is going to focus his ministry to reach this class he has to realize that his annual baptisms will not be in the hundreds. It is difficult to win many of this class, some might be converted, but it must be recognized that their conversions will not be large. ${ }^{2}$ Hence the conferences would have to recognize that this individual is on a special project, ${ }^{3}$ so it becomes necessary to devise a method of recognition that will accommodate this."

With the assumption that conferences are sovereign in regard to the administration of their affairs, and they have all identified a common problem, why not exercise their sovereignty and construct a ministry to address the problem?

The East Jamaica Conference president replies:

'Bennett interview, February 1996.

${ }^{2}$ For obvious reasons. When compared to the 2.5 million people in Jamaica, this class numbers just a few thousand. However, in the context of the great commission and their immense influence, they need to be reached as well.

${ }^{3}$ The EJC president argues that this would be a problem. creating a separate system of recognition for people working for classes would not resonate with pastors within the conference or the Jamaican society's strong sense of nationalism. He further comments that local churches would contend that all are one at the foot of the cross, hence the special treatment. (The strategy proposed by this research, if properly implemented, should prevent these problems from occurring.)

${ }^{4}$ Mckinney interview, 1996. 
While it is true that each conference enjoys a measure of sovereignty, it is limited self-government. our policy and regulations are handed down to us. Conferences who go contrary to the general means of recognition are relegated to a lower status, such as being labeled unproductive and not keeping the goals of the higher organization.

At year-end Division meetings evangelistic goals are given to the Unions who divide them between the conferences, who divide between the pastors who divide between the churches. No one ever stops to ask what kind of people are coming in, the focus is not people but numbers.

A president or administrator who wishes to serve at another level of the church perhaps would not be considered if he [chooses to take an approach to his evangelism that would not accommodate the higher system of recognition]. Change to this cycle of recognition and promotion of evangelism cannot come from below, it has to come from above.'

When asked if he thinks that the Seventh-day Adventist ministry avoids upper-class evangelism, the West Indies Union president answered in the affirmative. He said:

The results will be few. Pastors who target this group will not be considered as progressive ministers. At the end of the year a pastor might baptize two or three from this group. The minister is locked in a system that calls for big baptisms. We need to develop a program where successful pastors who are established, and to whom numbers are no longer viewed as significant, target the higher class as a special project.

If a young minister out of school targets this group and his annual baptism is very small, then he might not be called, he might not be looked at, he might even be jettisoned.2

The method of evangelism is a well-recognized barrier

in the evangelization of the upper classes. A solution needs to be pursued, but exactly how to go about this calls

'Bennett interview, February 1996.

${ }^{2}$ Ibid. 
for training or maybe specialized ministers and ministry. This is the idea that is held by some of the leaders who were interviewed. It will take a specialized and focused form of evangelism.

\section{Seventh-day Adventist Lifestyle and Culture}

The SDA Church has developed and matured into a culture of its own. It has its own schools, facilities, amenities, network of institutions, even "language" and jargon. Someone can easily be born into the Adventist church, attend church schools, work for church institutions, retire within the church, use church hospitals, receive sustentation from the church, die, and be buried by the church. The church has its own culture and it is a community with an entire lifestyle of its own.

A culture is resistant to whatever is dissimilar to itself. Nancy J. Adler, in her work Organizational Behavior, defines culture as "a way of life of a group of people, the configuration of all, the more or less stereotyped patterns of learned behavior, which are handed down from one generation to the next through the means of language or imitation."1

The church has its own distinct style of worship, its own style of government that is at times non-communicative to the uninitiated, and its own jargon, such as "quarterly,"

${ }^{1}$ Nancy J. Adler, organizational Behavior (Boston, MA: PWs-Kent Publishing Co., 1991), 15. 
"A.Y.," "Ellen White," "the Spirit of Prophecy," "the truth," "the Sabbath," "remnant," etc. Paulien puts it this way:

As Adventists we have our own in-house language. We have our own special way of reasoning to a conclusion. Just the thought of ten secular people walking in and sitting down in the church would drive the average Adventist pastor to distraction. What should he say? And how should he go about saying it? Seventh-day Adventists are rightly concerned about finishing the work. But if we are really serious about it we need to learn how to speak to secular people.'

The unique culture that is comfortable to the average SDA can form a barrier to the average outsider.

The upper classes resist non-traditional churches perhaps because non-traditional churches are not only viewed as cultish or sectarian, but as narrow and exclusive. One of the major contributing factors could be the usage of jargon. Jargon communicates exclusivism. only the initiated are welcome. The SDA jargon can also communicate insularity and exclusivism, which those in the higher classes would resist.

The upper-class communities are very active in the life of the nation. They perceive the traditional churches as more inclusive. Part of the reason could be because the language of the traditional churches reflects felt issues and concerns of the wider community and the nation, therefore those in the higher classes can resonate with the views of traditional churches.

\footnotetext{
${ }^{1}$ Paulien, 42 .
} 
Rick Warren, writing on effective strategies to reach the secular class, stated that in order for the average church to be effective in its evangelism it has to learn from its targeted group who they are and allow that knowledge to determine how it will attempt an evangelization of the group. He said that fish must be caught on their own terms.

Catching fish on their terms means letting your target determine your approach. When you go fishing, do you use the same kind of bait for every kind of fish? . . You must use the bait and how that bait matches the fish you want to catch. ${ }^{1}$

He further argues that methods should be changed whenever it becomes necessary. ${ }^{2}$

The secular rich, those who are uninitiated, do not find the SDA culture conversant with their culture. SDAs seem to be a closed culture to those on the outside. Another practice within the SDA culture is the authoritarian approach that some leaders take in their ministry. The wife of a member of Parliament in the district where I pastored commented on this. She said she was surprised at my friendliness and outreach. The few SDA ministers she encountered carried an excessive air of authority. This perhaps could be due to the fixation on the part of some ministers in enforcing what they perceive to be

\footnotetext{
${ }^{1}$ Rick Warren, The Purpose Driven Church (Grand Rapids, MI: Zondervan Publishing House, 1995), 196.

${ }^{2}$ Ibid. , 199.
} 
the rules of the church. This results in a habit on the part of some to take a rule-oriented approach to ministry rather than a people-oriented approach.

Eugene H. Peterson's comment is noteworthy on this practice.

When men and women get their hands on religion, one of the first things they often do is to turn it into an instrument for controlling others, either putting or keeping them "in their place." The history of such religious manifestations and coercion is long and tedious. It is little wonder that people who have only known religion on such terms experience release or escape from it as freedom.'

Lee strobel argues that it is erroneous to attempt to coerce the unchurched, especially those in the secular community. They do not like being told what to do. Such people resent being told to live a certain way because the Bible says they should. They are not yet convinced that the Bible is God's revelation. Such people also think that they are best qualified to decide what rules to live by. ${ }^{2}$

The West Indies Union president, commenting on the SDA culture as a barrier in reaching the secular in the upper class, says, "The SDA lifestyle in terms of some of our dietary practices, what to drink, no smoking, is not attractive to these people with money." ${ }^{3}$

'Eugene H. Peterson, The Message (Colorado Springs, Co: Navpress, 1993), 338 .

${ }^{2}$ Strobel, 49.

${ }^{3}$ Mckinney interview, February 1996. 
One word of caution: It is not to be understood that this report is suggesting that the SDA culture and lifestyle in its entirety are unattractive to the secular community. There are elements within the church life that appeal to the secular community. "Our health system," "our educational system,"l "the peace which the church contributes to the community by not adding any more people to the courts, 12 are a few of the practices of the church that they find attractive. The former Catholic Archbishop of Jamaica adds that along with the remarkable contribution in education that the Adventist church is making to nation building, "the members of the SDA church are normally of high moral character, especially in the context of honesty and responsible work ethic." ${ }^{3}$ These are practices among SDAs that are very attractive to some among the secular rich. However, this cannot detract from the fact that there are practices within the life of the church as an institution that can communicate exclusivism and give the impression of insularity to those who are not members. The East Jamaica Conference president said that the office of the Governor General of Jamaica informed him that they will not send any more correspondence to SDA churches. The office states that when correspondence is sent, they receive

'Donald Kent, interview by author, February 1996.

${ }^{2}$ Reid interview, February 1996.

${ }^{3}$ Carter interview, February 1996. 
no response. They feel completely ignored and insulted. "There is not even the benefit of an apology."1

This is a perception that is reported to be shared also by the former president of the Jamaica Council of Churches. The SDA church is an insuiar group, concerned only with itself." This could be the reason why "nothing we do as a church attracts the media."

The general conduct of the church, by some of its priorities, lifestyle, and inner cultural habits, seems to make the statement that it wants to be left alone.

Theological Distinctives

Some of the church's theological teachings could possibly be cited as another barrier impeding the attraction of the upper classes. This idea is shared by Silas McKinney, West Indies Union president. Some of the church's teachings might not resonate with this group. The church preaching on Ellen $G$. White might convey the impression that the SDA church is a cult. "The cult-phobia" is popular in this community. It can cause them to stay away."

The seventh day of the week as the Sabbath is another teaching that is a barrier. The upper class view this

\footnotetext{
'Bennett interview, February 1996.

${ }^{2}$ Ibid.

${ }^{3}$ Ibid.

${ }^{4}$ McKinney interview, February 1996.
} 
emphasis as unnecessary. They contend that the day of worship is irrelevant.' The doctrine of the Sunday Law and other churches as the "beast" or "apostate Protestantism" are doctrines that do not resonate with the secular rich who traditionally hold membership within these churches. Many of the political and government community leaders are members of these churches; they view such teachings as subversive, hostile, uncharitable, and fostering a spirit of belligerence and alienation. ${ }^{2}$

\section{Materialism}

The popular observation by all the SDA leaders who were interviewed was that materialism is a major barrier that prevents the upper class from accepting the gospel. The comments of the SDA leaders are:

West Indies Union: "History has revealed that people with money do not go to non-traditional churches."

West Jamaica Conference: "This group is satisfied materially. Those who accept christ need some crisis. This class feels no material need."

'Ibid.

${ }^{2}$ In conducting this research, I visited the former Catholic Archbishop, Samuel Carter, who expressed hurt at being attacked as such, said to me, "If you have to preach it, preach it. But I wish we could just talk with each other." 
East Jamaica Conference: "Often these people are too busy making the second million, they have no time for God. The self-sufficient do not feel the need for God."

Acting Head of West Indies College Theology Dept.:

"Not only the SDA church is ineffective in reaching this class, even the non-traditional churches. This class is devoted to materialism and self."

The common view is that those who are fixated with the acquisition of wealth apparently have little time for religion or God.

\section{Conclusion}

It has been demonstrated that there are at least seven barriers preventing the SDA church from making an impact on the upper-middle and upper-class community. The barriers identified are historical factors, perception, secularization, institutional practices, Seventh-day Adventist culture, theological distinctives, and materialism.

Does this mean that the church cannot reach this group? This report does not affirm this view. The gospel commission contains no reticence within it, it commands the gospel to be taken into "all the world, to every nation, kindred, tongue and people" (Rev 14:6). This includes all the classes.

The SDA church in Jamaica has been effective in evangelizing the masses who are largely from among the lower 
class. The evangelistic strategy that has proven very effective has been the use of tents. This should continue. Tent evangelism has been and still continues to be effective in reaching the masses in Jamaica and should be encouraged. It would be ludicrous to remove something that is effective. But there are other groups of Jamaicans to be evangelized. Two such groups are the upper class and the upper-middle class. Tent evangelism has not made any impression in attracting this group. The church needs another strategy to reach them. 
CHAPTER 4

\section{INTENTIONAL MINISTRIES AS A SUGGESTED APPROACH FOR REACHING THE MIDDLE-UPPER \\ AND UPPER CLASSES}

This chapter proposes to suggest an approach that, with careful implementation, should prove effective in reaching those within the upper-middle and upper-class communities of the Jamaican society with the Seventh-day Adventist message.

\section{The Need to Reach This Group}

Ernley Gordon, the erudite Anglican priest and religion columnist for Jamaica's national paper, said, "There has never been in the history of Jamaica a mission to the rich."' The popular perception of Jamaica's SDA leadership is that the upper classes who attend church hold membership among the Anglicans and the Catholics. ${ }^{2}$ But as noted above, when interviewed concerning this perception, the Anglicans report that the upper-class communities attend the catholic church, while the catholics contend that they belong to the Anglicans. The conclusion of this report is that the upper

'Gordon interview, February 1996.

${ }^{2}$ This is the view of the Acting Chairman of the Department of Religion, West Indies College, and the West Indian Union president. 
classes are neglected by all church groups. Gordon's view appears to be accurate: the churches apparently have never carried out a deliberate mission to reach the upper classes in Jamaica.

Ellen White advises the church to devote attention to the "neglected rich. Many look upon this class as hopeless, and they do little to open the eyes of those, who, blinded and dazed by the glitter of earthly glory, have lost eternity out of their reckoning. Thousands of wealthy men have gone to their graves unwarned."I

The SDA church must reach the higher classes.

Additional commands by the church's prophet and messenger are as follows:

The gospel invitation is to be given to the rich and the poor, the high and the low; and we must devise means for carrying the truth into new places, and to all classes of people.

First reach the high classes if possible.

Plan to reach the best classes, and you will not fail to reach the lower classes. ${ }^{2}$

God calls for workers to reach those in the higher classes, who, if converted, could in turn work for those of their own standing.

Those who belong to the higher ranks of society are to be sought out with tender affection and brotherly regard.

We talk and write much of the neglected poor: should not some attention be given to the neglected rich?

'Ellen G. White, The Ministry of Healing (Mountain View, CA: Pacific Press Publishing Association, 1947), 210.

${ }^{2}$ Ibid. 
There has not been the effort made that should have been made to reach the higher classes.

In order to do this workers will have to keep themselves up to a high level of intelligence. . . . One reason why efforts have not heretofore been made for the higher classes as I have presented before you is a lack of faith and real courage in God.

The intelligent, the refined, are altogether too much passed by. The hook is not baited to catch this class, and ways and methods are not prayerfully devised to reach them.'

The upper classes hold considerable influence within Jamaica. The political and economic machinery, to a large extent, is under their influence. They are the thought leaders of the nation and influence the direction the country takes.

The Seventh-day Adventist Church follows what Avery Dulles calls the herald model of ministry. The church sees its mission in the world to "proclaim that which it has heard, believed, and been commissioned to proclaim."2 The church understands itself to be the proclaimer of the three angels' messages. ${ }^{3}$ This message is to be preached to "every nation, tribe, tongue, and people" (Rev 14:6).

Obedience to the counsels of Ellen White, the inspired messenger of the Seventh-day Adventist Church, ${ }^{4}$ and to the

${ }^{1}$ Ibid., 552-556.

${ }^{2}$ Avery Dulles, Models of the Church (New York: Doubleday Publishers, 1987), 76.

${ }^{3}$ Seventh-day Adventists Believe: 27 Fundamentals (Hagerstown, MD: Review and Herald Pub. Assn., 1987), 164.

${ }^{4}$ Ibid., 224. 
mandate of the remnant church,' concomitant with the fact that there has never been a mission to the upper classes in Jamaica, challenges the church to attempt to reach that group.

\section{Can They Be Reached?}

The proclamation of the everlasting gospel among the materially and financially privileged will call for different methods of evangelism than those that have been effective in reaching the lower classes.

People who comprise the lower class in Jamaica are more communal, they live in villages. There are not many choices available to them at the end of their daily activities. Those with more money and material amenities have a wider range of choices. It is perhaps due to the limited choices available that a tent placed in a town or village will be attractive to the residents of the lower class in that town or village. The novelty of a tent meeting is an alternate choice for the evening's entertainment, and a distraction from the routine. The lower class attends and some conversions result among those in attendance.

The strategy of tent evangelism does not impact the higher class who have the benefit of wider choices. With this reality facing the church "methods [must] be devised to

\footnotetext{
'Ibid., 163.
} 
reach the higher classes."I The hook must be baited to catch this class. Ways and methods must be prayerfully devised to reach them. ${ }^{2}$

Jesus and the Upper Classes

Did Jesus reach the higher classes? The New Testament makes it plain that He did. Matthew, Zaccheus, Joseph of Aramathea, and Nicodemus are representative of the upperclass community who were successfully reached by the Lord. Not all among the upper class turned from the call to discipleship like the rich young ruler.

How did Jesus reach this class? Ellen White states that "great men, learned men, can be reached better by the simplicity of a godly life." ${ }^{3}$ Not unlike Nicodemus, many of the higher classes were attracted to Jesus by the Lord's godly life, by His service to humanity, and by His care and concern for the needs of people within the communities. Matthew is representative of those among the higher classes who aligned themselves with Jesus, followed Him, and assisted in serving people and their various needs. Zaccheus is representative of those in the upper class who see the church as a medium through which they can give back goods and services to the community. Nicodemus represents those

'Ellen G. White, Evangelism (Washington, DC: Review and Herald Publishing Assn., 1974), 553.

$$
\begin{aligned}
& { }^{2} \text { Ibid. , } 556 . \\
& { }^{3} \text { Ibid., } 557 .
\end{aligned}
$$


in the higher classes who labor for their colleagues such as Joseph of Aramathea, or those priests converted in the book of Acts.

The New Testament testifies that the Lord did reach people within the upper classes. The church today, in its responsibility in following the Lord, must also follow Him in reaching out to the upper classes. But it will call for a different form of evangelism to reach the higher class than the ones used to reach the lower class.

It is by no casual, accidental touch that wealthy, world loving, world-worshipping souls can be drawn to Christ. These persons are often the most difficult to access. Personal effort must be put forth for them by men and women imbued with the missionary spirit. ${ }^{1}$

The number of people Jesus won from among the higher class was not as extensive as those He won from among the lower class, but like Nicodemus and Joseph, the higher class can use their influence in expanding the gospel in ways the lower class cannot. Leadership within a local community and the nation at large generally comes from the upper class. History plainly teaches that when the elite of society place their influence on the side of promulgation of the gospel, progress accelerates in ways those of lesser influence could not have achieved. Therefore, "personal effort must be put forth for them."

\footnotetext{
'White, Ministry of Healing, 213.

${ }^{2}$ Ibid.
} 
It will take deliberate, intentional, personal strategies to reach this group. All members of the church might not be able to work for the evangelization of the upper-class group. The church has to identify, equip, and empower those who are "especially fitted to work for the higher classes."I I am convinced that if the SDA church will "plan to reach the best classes, [it] will not fail to reach [more of] the lower classes."2

\section{Intentional Ministries}

The dissertation has shown that the church in Jamaica has not been effective in making contact with the upper classes. In order to be able to reach them the church will have to make contact, for it is only after contact is made that opportunities for evangelization are possible. contacts can lead to friendships. It is within the context of these friendships that people become SDA Christians. ${ }^{3}$ Presently there is very little contact between the upper classes and the church. Both groups, for reasons discussed in earlier chapters, are isolated and insulated from each other.

'Ibid.

${ }^{2}$ White, Evangelism, 553.

${ }^{3}$ Monte Sahlin, Sharing our Faith with Friends without Losing Either (Washington, DC: Review and Herald Pub. Assn., 1990), 50. 
Intentional ministries can be used as bridges by the church to make contact with the upper classes. Then contacts will lead to friendships that can make friendship evangelism possible.'

\section{Definition}

What are intentional ministries? Intentional ministry is any social ministry, instrument, or program created and designed by the church to make a constructive impact or difference within the local community. The social needs of communities are many. The church as a caring "change agent" can identify the various needs and take the initiative to provide leadership towards the care and alleviation of those needs.

How does it work? The church studies the community, locates the social concerns, hurts, and exigencies within the community, then proceeds to initiate community-church programs to attend to the identified needs. Ernley Gordon, the Anglican bishop, calls these initiatives "redeeming the community." ${ }^{3}$ Communities are in need of redemption, they are hemorrhaging in many areas. There are many social concerns, dysfunctions, and cries for help.

'Ibid.

${ }^{2}$ Lyle A. Schaller, The Change Agent (Nashville: Abingdon Press, 1972). (See introduction.)

${ }^{3}$ Gordon interview, February 1996. 
The name "Intentional Ministries" is chosen because, in order to effectively reach the upper class by way of these ministries, nothing can be left to chance. The church that wishes to labor for the evangelization of the upper class has to be clear and focused in regard to its objective. All aspects of the chosen ministries have to be carefully supervised towards the realization of the objective.

\section{Social and Community Concerns}

What are some social and community concerns in Jamaica? I will rely on the newspaper column written to carl stone, an internationally renowed scholar, pollster, newspaper columnist, political activist, and author to assist in the provision of an authoritative response to the question. Stone's polls, analysis, and articles on economic, political, and cultural issues for twenty years have shaped Jamaica's public opinion.

According to stone, some of the social and community concerns in Jamaica are crime, violence, poverty, unemployment, health, domination of family, illiteracy, housing, drug abuse, and the decline of traditional values.

'Carl Stone wrote for Jamaica's national newspaper on issues of concern to the country. After his death February 26, 1993, his Gleaner columns of 1992-1993 were collected by Rosemarie stone. The stone columns is the result of this collection.

Many Jamaican political, social, and thought leaders endorsed the credibility of stone's work by writing tributes. This work is one of the few that would be an authoritative current bibliographic source on Jamaica's social and community problems. 
Writing on poverty and violence, stone says, "There is no longer any need to guess or speculate about this issue. A great deal of research has been done on it both at the international level and in our own environment and the explanations are beyond refutation." In documenting the increase of violent crimes in the country since its independence in 1962 he wrote:

The numbers of assaults per 1000 of population increased from 120 in the 1950 s to 300 by the end of the 1960 s and climbed to 650 by the late seventies. - . Homicides and killings grew from five to 100,000 of population to 11 in the late sixties and up to 20 by the late 1970s and early 1980s. Personal robberies jumped from 15 per 100,000 of population to 30 by the end of the sixties and climbed further by the late 1970 s.

Jamaicans have always been poor. Poverty did not begin in the 1960s, so poverty by itself cannot explain these escalating trends in violent crime. ${ }^{2}$

Jamaican communities also have a

drug trade problem that has given the gunmen real economic power. . . . In any society where badness and appetite for money destroys traditional values and sidelines education, professionalism and the impulse towards moral and intellectual growth, decay is inevitable. . . . If we don't change these values God help us in this country. ${ }^{3}$

Housing is another problem. "Today, great problems are being experienced in generating adequate housing for the

\footnotetext{
'Stone, The Stone columns, 30 .

${ }^{2}$ Ibid., 31 .

${ }^{3}$ Ibid. , 33 .
} 
poor because of the huge gap between housing costs and the declining real income." Stone further comments,

Many of our social problems link directly to poor housing. Overcrowding, aggression, crime, undiscipline, street corner gangs, exposure to hard drugs and deteriorating academic performance by males are all part of a syndrome of problems linked to inadequate housing. ${ }^{2}$

Education: Illiteracy is another problem being experienced in Jamaican communities.

The low levels of expenditure on maintaining school buildings and infrastructure, the abominably low salaries we pay teachers, the low and declining level of per capita expenditure on students at primary and secondary levels of our education system, the vandalism of these fixtures and buildings by our citizens, the poor management of most of our educational institutions, and the low priority we as a country and as parents have given to education, all indicate that as a people we have no regard for education and educational development. ${ }^{3}$

\section{Attempts at Resolution}

What attempts are made by the country to attend to these problems and how effective are they?

The government has addressed the problem of crime by increasing the numbers and fire power of the police force. In regard to the problem of teenage pregnancies, the government funds advertisements recommending the use of condoms. Clinics are also funded to assist in the distribution of condoms. On the problem of housing, the

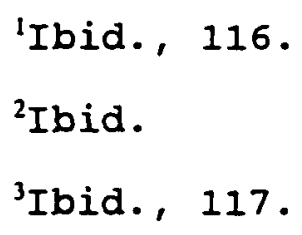


government set up the Jamaica National Housing Trust to construct low-income houses.

Community Problems and the Upper Classes

While these solutions are pursued, social and community problems continue and are increasing. This has caused no small concern within the nation.

Oliver Daley, who pastors the Webster United Church in Kingston, Jamaica, where a few of the upper classes attend, identifies crime and problems within local communities as one of their major concerns.' To address these concerns, the upper classes arrange meetings with community leaders to discuss the possibility of solutions.

Carl stone attended one such meeting and wrote, "Representatives from some 16 government agencies attended in an effort to devise new strategies to improve and enhance the services they deliver at the community level."2

The practice of the upper classes in showing concern at the local community level is not new. ${ }^{3}$ They have lent their influence and money to the developing of the local community even if it has been to "pacify black discontent." 4 Many

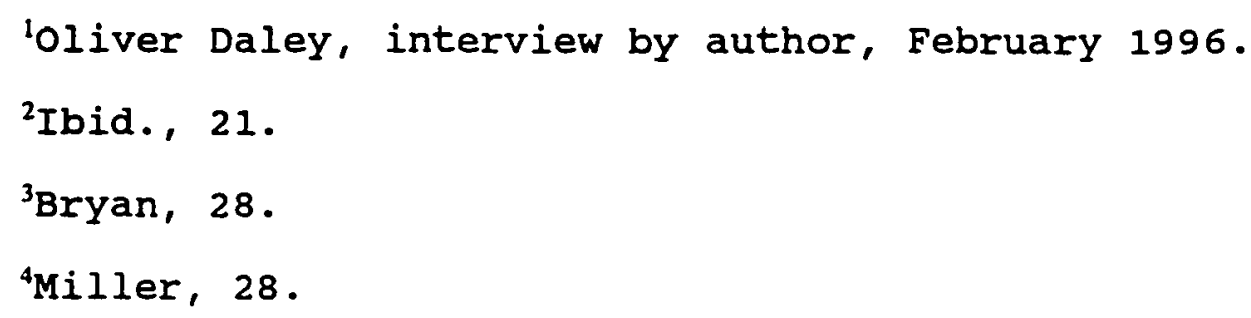


schools, educational facilities ${ }^{1}$, and hospitals ${ }^{2}$ have been built with monies from the upper classes.

The upper class has funded and supported many initiatives within local communities in attempts to bring under control the social unrest. Many of these initiatives have been funded through government agencies. Programs that are funded by the upper classes through government agencies are viewed as government programs. However, these programs have not been successful:

Jamaica has a long tradition of community development initiatives but their effectiveness has been limited due to fragmentation, inadequate resources, isolated work by agencies, lack of national support, weak organization and the exclusion of communities and community leaders from having any say in the development process. ${ }^{3}$

The suggestion by the conference on community

Development is as follows:

For integrated community development strategies to work, the idea has to gain acceptance within Jamaican communities islandwide, and ordinary citizens have to feel that by participating in the management of their communities they can make a difference in how things run in their local areas. ${ }^{4}$

The Role of the SDA Church

It is within the milieu of these concerns that this report seeks to recommend Intentional Ministries as an

\author{
'Bryan, 30. \\ ${ }^{2}$ Ibid., 71. \\ ${ }^{3}$ stone, The stone columns, 21. \\ ${ }^{4}$ Ibid., 22.
}


approach which the SDA church can use to reach the upper classes. The local communities are suffering from diverse social dysfunctions. The upper classes are concerned. They are concerned about the crime, the drug culture, the erosion of traditional values, the decline of the family, health issues, unemployment, youth and violence, etc. This privileged class attempts to implement programs to arrest the problem. Many of these programs have not been very successful. Stone describes why these programs appear not to work. He contends that this is due to failure to gain acceptance island-wide, and ordinary citizens have to feel that by participating in the management of their communities, they can make a difference.

There is also the problem of "fragmentation, inadequate resources, isolated work by agencies, lack of national support, weak organization and the exclusion of communities and community leaders from having any say in the development process." "1

Stone, a member of the middle-upper class, an intellectual, a highly respected academician and thought leader for the upper classes in Jamaica, proposed the following solution to the frustration being experienced by the communities.

1. Cost sharing of project expenditures between government and communities.

\footnotetext{
'Ibid., 21.
} 
2. The use of schools as resource centers to facilitate community development.

3. The empowerment of citizens to have a say in how communities are managed.

4. Mobilizing both community and private sector input into local development.

5. Organizing newly created community leaders and groups into constituency . . . to speak on behalf of the poor.'

Writing on another community problem and the social

aberrations being experienced by the Jamaican communities,

Carl stone asks,

Where are the MPs [members of Parliament] and church and community leaders in all of this? Part of our problem here has to do with irresponsible attitudes by citizens and weak and enfeebled leadership that does not have what it takes to bring discipline to the communities and to the management of public amenities. ${ }^{2}$

The higher classes, the government, and even the thought leaders are looking for solutions to the problems being experienced by the communities. It appears evident that these groups would be willing to fund and to align themselves with any initiatives, properly organized, that will pursue community solutions. The government and the upper classes have tried but "political tribalism, the tradition of welfare hand-outs and dependency that undermines community impulses towards self-help, weak leadership" ${ }^{3}$ have limited their effectiveness. Hence many

'Ibid., 24. Other propositions were made, but those conversant with the approach being discussed were selected.

${ }^{2}$ Ibid., 119.

${ }^{3}$ Ibid. , 21. 
communities "have lost confidence both in government agencies and elected public officials."1

Leadership in community-development initiatives has been attempted by the upper class. "Jamaica has a long tradition of community development initiatives but their effectiveness has been limited due to.. . the exclusion of communities and community leaders from having any say in the development process." 2 The problems remain. What can be done? Can a solution be pursued that will incorporate the suggestions proposed by Carl stone and avoid the barriers and pitfalls normally experienced by other community initiates as was identified by the Community Development Committee? This study proposes that Intentional Ministries can be the answer.

The Seventh-day Adventist Church is equipped to provide leadership within the context of this problem. The SDA churches in their local communities are agencies already organized, with local personnel, to staff community initiatives. Pastors of the local SDA churches can formulate and organize community initiatives in their local areas.

According to Stone, some of the major obstacles to effective community development work were . . political tribalism, apathy, the tradition of welfare hand-outs and

$$
\begin{aligned}
& \text { 'Ibid., } 22 . \\
& { }^{2} \text { Ibid., } 21 .
\end{aligned}
$$


dependency, that undermines community impulses towards self-help, weak leadership, the absence of community organizations within most communities and limited financial and manpower resources available to the agencies to tackle community projects on the scale required for real effectiveness.'

A church-supported, church-organized, church-led, church-sponsored community initiative would be without many, if not all, of the forementioned obstacles. The church is not a political entity, therefore it would not be partisan in supervising community initiatives. Churches command respect in communities and are attractive for uniting communities. The church is already an organized unit within the community that commands an extensive network of volunteers and departments. There are the Youth, Education, Community Services, Adventist Disaster and Relief Agencies, and Health departments. The church is organized to be a force within its local community. With careful leadership and visioning, this can be realized.

The local SDA churches can lead out in the developing, designing, and creating of initiatives to impact their respective communities. It is these initiatives that this report chooses to call Intentional Ministries. The church would identify the community needs and approach the civic, business, and other local community leaders (many of whom are from the higher classes) with project proposals.

\footnotetext{
'Ibid., 21.
} 


\section{SDAs, Upper Classes, Lower Classes, and Intentional Ministries}

"First reach the high classes. . . Plan to reach the best classes, and you will not fail to reach the lower classes."' The upper classes are insulated and isolated from the church. The church itself is insulated and isolated from the upper classes. In order for evangelism to take place, contact will have to be established. It is incumbent on the church by virtue of her mission and reason for existence to study how to make this contact. I am suggesting Intentional Ministries as that point of contact. The upper classes carry strong concern for the community and its social problems. The church can capitalize on this concern and use it as a medium to make contact with the upper classes.

The church will identify the social problems in the community, bring them to the attention of the community leaders, and propose Intentional Ministries as solutions. Intentional Ministries are not to be staffed, funded, or led only by church members, but community leaders and members of the upper classes will be called upon to lend their influence, time, and leadership to these ministries.

The church and the upper classes will be working together formulating ideas, creating agencies, and targeting areas to establish ministries to address community problems.

'White, Evangelism, 553. 
Agencies such as literacy classes, health clinics, family life seminars, parenting skills workshops, cooperatives to address the problem of housing, disaster teams, media programs, clothing relief agencies, youth clubs, sports organizations, and drug awareness in schools are just a few ministries that could be intentionally created to address the problems faced by the communities.'

It is imperative that the church understand itself to be leading out towards a church- and community-sponsored solution. It must not take the approach that the initiatives ${ }^{2}$ to be pursued are solely church sponsored, or under the sole auspices of the church. This is not the case. The church is bringing its resources, its experience, its leadership, its intellect, its members, its money, its credibility to the community, to pursue improvement and development of the community in which it lives, functions, and operates.

\footnotetext{
'It is not the goal of this report to define or name each and every possible community ministry. This is to be done in a think tank with upper-class members, the church, and other community personnel. The church's task is to lead out in the initiatives. Within this group the problem of identifying areas to be addressed, funding, and resources will be discussed and solved. The goal of this report is to prepare a strategy to bring the two groups together.

${ }^{2}$ The paper calls these initiatives Intentional Ministries. They are so labeled because of the focus of intentionality within it. These ministries are deliberately designed to make a redeeming impact on the community, to deliberately initiate community improvement.
} 
88

The upper-class community must be deliberately sought out, not to pursue a solution already worked out by the church, but to participate in solutions towards redeeming the community. The church role is to provide leadership or total support of these community initiatives.

\section{Purpose}

The purpose of this community participation, the purpose of Intentional Ministries, is to find a common ground to remove both the church and the upper classes from their isolation and insulation and bring them into contact with each other. Intentional Ministries can be the bridge that both groups need to establish contact. After contact has been established, then the church can begin to seek opportunities to evangelize the upper classes.

\section{Will the Upper Classes Support} Intentional Ministries?

It has been made evident that the upper class holds strong interest in pursuing solutions to the problems of the communities. Another reason why the upper-class communities in Jamaica would incline towards Intentional Ministries is that there is a strong history and orientation among the middle and upper classes in the society towards being philanthropic.' Patrick Bryan, a senior lecturer in the Department of History at the University of the West Indies,

\footnotetext{
'Bryan, 3 .
} 
did a historical survey of philanthropy in Jamaica. His book reveals that the upper classes in Jamaica, since the early 1500 s to the present, has a history for being philanthropic despite their history with slavery. The wealthy view the need to give back to their community as their "social responsibility."l

If this has been the case, how could the wealthy have enslaved the "lower class"? Bryan responds:

The complex process of the abolition of slavery has attracted the attention of many historians. Those who accept the Eric Williams thesis give pride of place to economic and material factors in slave abolition. other historians have placed some emphasis as the increased incidence of slave revolts. However we need not take up here a position for or against materialism or idealism in the abolition of slavery. Anti-slavery was, in part, "an extension of a philanthropic tradition" which had gained in strength since the sixteenth century. Philanthropy had always been a part of the aristocratic ambience, but the merchant elite, lacking in inherited status, found, increasingly, that they could prove their "moral worth" by assisting the less fortunate. ${ }^{2}$

Bryan went on to demonstrate in his book that the Jamaican society developed due to cooperation between the upper and the lower classes. Community leaders initiated ideas for the development of roads, the education system, and medical care, among others. In many cases funding was received from the upper classes. ${ }^{3}$

\footnotetext{
'Ibid.

2Bryan, 11.

${ }^{3}$ Ibid. , 17-30.
} 
In a very real sense, Jamaican society became more, not less complex, in the period following the abolition of slavery. Between 1838 and 1938, organizations multiplied, reflecting educational, religious, moral, family concerns, the problems of children, women, juveniles, widows and orphans. Philanthropic and voluntary works, dominated by the more leisured upper classes.

In Jamaica today, as it has been demonstrated, there are still many social problems within the communities. M. G. Smith, a Jamaican anthropologist, retired professor in the Department of Anthropology at Yale University, writing in 1989 on a survey conducted in the Jamaican society to enumerate the poverty in the country, said:

The needs for social assistance that this survey tried to measure are many and various. Besides employment and cash income, the list, rough in the order in which they are reviewed below, includes needs for vocational training, for land, for housing, for health services for adult and children, the needs of the aged, destitute and the indigent handicapped; the needs of families for insurance coverage of some kind, the needs of children and poor families for help with children; the needs of illiterates for Iiteracy, of men and women for guidance on family planning, of poor people for free legal aid, and for information on the social issues and provisions available for their relief."

Smith's findings are staggering. The social needs within the communities are great. The upper classes are aware and have traditionally participated favorably in initiatives to arrest the problems.

I'Ibid., 31 .

${ }^{2}$ M. G. Smith, Poverty and Wealth in Jamaica (Kingston, Jamaica: Institute of Social and Economic Research, University of the West Indies, 1989), 7. 
Oliver Daley, pastor of the Webster United Church in Jamaica and a family counselor on Jamaica's leading radio station, mentioned to me the success he has had in providing care for the community in which his church serves. His church ministers to the community by providing a home for the aged, primary education, a clinic, and a counseling center. He says he does not discriminate; the provisions are for the community, no special class.'

Daley's church is supported with attendance from members of the upper classes. Could it be possible that the reason why Oliver Daley's church in Kingston, Jamaica, is supported by the upper class is because they view his church as making a difference in the community in tangible ways and they want to participate?

This certainly is the case of Mother Theresa, the Catholic nun who has committed her life to working for the poor in the slums of India. Many professionals, academicians, youth, university graduates, and wealthy journey to Calcutta to give their support.

Edward Le Joly, in one of the many books written celebrating Mother Theresa's work, wrote,

Hundreds of people have come to offer their service -. . They come from France, Belgium, England, the United States, Canada, Germany, the Netherlands, Italy,

'Daley interview, February 1996. 
Malta, the Scandinavian countries, among others. Most of them . . Young, open-minded and generous.'

Mother Theresa's social contribution has so influenced the world that many missions have developed with the aim of "spreading Teresa's work throughout the world." Her efforts have attracted nations, kings, princes, and princesses. Wealthy people have even given up their wealth to give their life to God and to serve alongside her. ${ }^{3}$

There is a need in people for a sense of purpose and meaning. One of the ways in which this is satisfied is in helping to alleviate the needs of people. Those with money always want to make a contribution.

\section{Summary}

It can be argued that the motivation on the part of many of the upper class in supporting social initiatives is not always altruistic.

The concern of the church must not be the initial motivation of the upper classes, rather the concern must be twofold: to be genuine in its contribution to its community and to bring about contact with the upper class so that

'Edward Le Joly, S.J., Mother Teresa of Calcutta (San Francisco: Harper Row Publishers, 1983), 336.

${ }^{2}$ Robert Serrou, Theresa of Calcutta (New York: McGrawHill Book Company, 1980), 66.

${ }^{3}$ David Porter, Mother Theresa: The Early Years (Grand Rapids, MI: Eerdmans Publishing Co., 1986), 73. 
relationships can be formed which will lead to conversions among the upper class.

The suggestion to use Intentional Ministries as mediums for redeeming the community is not new; it is already the church's duty. "If any one has the world's goods and sees his brother in need, yet closes his heart against him, how does God's love abide in Him? Little children, let us not love in word or speech but in deed and in truth" ( 1 John $3: 17,18)$.

In writing on the relation between evangelism and social action, John $R$. W. Stott said,

We should not hesitate to agree with this... for there is a strong precedent for it in the ministry of Jesus. His words and His deeds belong to each other, the words interpreting the deeds and the deeds embodying the words. He did not only announce the good news of the Kingdom; he performed visible "signs of the Kingdom." If people would not believe his words, he said, then let them believe him "for the sake of the works themselves" (John 14:11). ${ }^{1}$

The primary goal of Intentional Ministries is to bring the church and the upper classes into relational contact working for the improvement and uplifting of the community. It is within this relational synergy that the ultimate goal of Intentional Ministries will take place, the evangelization of the upper class. ${ }^{2}$

'stott, 26, 27.

${ }^{2}$ Not only will the church gain access to the upper class, but it will also gain credibility in the nation as a constructive agency for community improvement. 


\section{Evangelistic Potential}

The goal of Intentional Ministries is to bring the two groups together. Presently there is alienation between the upper classes and the SDA church. As the report has demonstrated, there are very few members of this group within the SDA church. Some reasons for this have been identified in chapter 3. Barriers, however, can be hurdled. This report proposes that if the two groups are brought into contact with each other there can be made available access to evangelistic possibilities.

The coming together of the church and the upper-class community to work together on a common goal will inevitably create relationships. Irrespective of their status, privilege, office, or opportunities, people are people. When brought together it is inevitable that they will establish relationships. It is within these relationships that evangelistic potentials will be made available.

Retired evangelist and acting head of the Theology Department of West Indies College, K. G. Vaz, said that one of the best ways to work for the upper class is through personal evangelism.' This view is shared by all the presidents in the Jamaican field. The coming together of the church community and the secular rich will create the possibility for personal relationships to develop. It is these relationships that will result in evangelistic

\footnotetext{
${ }^{1} \mathrm{Vaz}$ interview, February 1996.
} 
opportunities. This is what E. G. White calls Christ's method of evangelism. "Christ's method alone will give true success in reaching people. The Saviour mingled with men as one who desired their good. He showed His sympathy for them, ministered to their needs, and won their confidence. Then He bade them, 'Follow Me.'"l

Intentional Ministries with a community focus, and administered on a community-church basis, is to bring both isolated and insulated groups into flesh-and-blood contact, so that "Christ's method" can be operational--the mingling of people.

Once the two groups start working together and relationships begin to be established, then prejudices, perceptions, and barriers will begin to erode. The attitude of the upper classes towards the church and the church towards the upper classes will begin to change. Church members will begin to see that these upper-class people face struggles not dissimilar to their own such as family concerns, parental frustrations, death, sickness, hurts, loneliness, rejection, marital problems, broken relationships, aging, the search for direction and truth, the need for purpose, the need for peace, the need for hope and meaning, the need for acceptance, understanding, friendship, and the need to be loved, among many others. The only difference between church members and people of

'White, Ministry of Healing, 143. 
upper-class status in the facing of these human problems is that the upper class might face them without God while SDA Christians face their problems with God.

\section{A Personal Testimony}

I deliberately sought out members of the upper-class community while serving as pastor for the Northern Manchester Circuit in Manchester, Jamaica, during the years 1990-1993. I became the personal friend of the families of members of parliament and with the local Roman Catholic priest. When the priest was being transferred to the United states, he recommended that I replace him on many local community boards. From these privileged positions I accessed many of the upper-class members of the community and friendships were established. I had been previously conditioned to believe that the upper classes were not interested in religion, religious issues, or God and those of a non-SDA persuasion were hostile to the seventh-day Adventist denomination. I was very surprised to discover that this was not the case at all. These communities simply did not know who SDAs were. They were aware of the church's existence, but they did not know who we were, what we stood for, or what we were about. They simply did not understand the SDA denomination or know what it taught.

I established many personal relationships. On visits to the homes of my secular rich friends, when their friends were visiting I was invariably asked to explain the SDA 
Church and its teachings. From these relationships I had a few Bible studies, many prayers, and positive responses. They were generous in supporting the programs of the church with their money and influence.

While pastoring in the oreabessa circuit of churches, in St. Mary, Jamaica, a rich developer contributed almost all the material for the building of one of the churches. When I asked him how we should go about repayment, he simply said to me, "The only payment I want from you is that you would befriend my wayward, rebellious son."

\section{Relational Evangelism}

With the church and the secular rich community working together towards the development of the community, relationships established between the upper class and the SDA church members will bring the members into contact with the felt needs of their upper class companions. This will open the door for relational witnessing.

In his book, Philip G. Samaan discusses the art of relational witnessing. He writes,

Jesus associated with people simply because He loved them and because He had their best interests at heart. . . People were His most important program, not because of their status or accomplishments, but because they were valuable in themselves.

This attitude must characterize Christians as relationships with the upper classes are fostered. People have cares,

'Philip G. Samaan, Christ's Way of Reaching People (Hagerstown, MD: Review and Herald, 1990), 46. 
concerns, and problems, and these are opportune times in people's lives for witnessing, sharing of a testimony and one's beliefs, a prayer, or calling for a decision to choose Christ.

with the realization that the primary way to reach the upper class is through personal contacts, the church that wishes to target this group has to deliberately develop the art of personal evangelism. In working for this group, there will not be major evangelistic campaigns utilizing the traditional forms of evangelism, rather the church members will have to be assertive and prudent in seeking opportunities to share their faith.' The church members must not wait for the non-member to take the initiative to establish contact, ${ }^{2}$ they must initiate the contacts, they must reach out to initiate, establish, and foster relationships.

\section{Implementing the strategy}

The Minister's Role

The minister is very important for effective implementation of Intentional Ministries as a bridge to establish contact with the secular rich in the Jamaican community. The minister is to be responsible for the

\footnotetext{
'Philip Samaan's book would be an ideal training manual for churches to be sensitized to the need of developing relational evangelistic skills.

${ }^{2}$ Ibid., 47.
} 
formation of the vision, creating involvement, fostering community-church networks, and equipping the church membership with the needed skills for effective participation in the Intentional Ministries.

It is to be noted, however, that to creatively work for the evangelization of the secular rich is not a calling for all ministers. Not unlike working in urban situations, it will call for special gifts, focus, abilities, and experience that not every minister will have. It will be necessary that those ministers who will work for the evangelization of the secular rich be convicted that they are called and burdened to do so. They must also be prepared to intentionally identify and develop the skills necessary to administer Intentional Ministries.

\section{Equipping the Laity}

As the minister works with the local congregation the roles and function of ministry have to be clear. It is imperative that the attitude on the part of some ministers to take a solo approach to ministry must be corrected. Ministry is not the prerogative of the pastor alone. Rick Warren puts it this way, "Every believer isn't a pastor, but every believer is called into ministry. God calls all believers to minister to the world and the church." 1 God has provided the church with the gifts to do ministry (Eph

\footnotetext{
${ }^{1}$ Warren, 368 .
} 
4:12). The SDA Church comments on spiritual gifts in the 27 Fundamental Doctrines.

God bestows upon all members of His church in every age spiritual gifts which each member is to employ in loving ministry for the common good of the church and of humanity. Given by the agency of the Holy Spirit, who apportions to each member as He wills, the gifts provide all abilities and ministries needed by the church to fulfill its divinely ordained functions. According to the scriptures, these gifts include such ministries as faith, healing, prophecy, proclamation, teaching, administration, reconciliation, compassion, and self-sacrificing service and charity for the help and encouragement of people. Some members are called of God and endowed by the spirit for functions recognized by the church in pastoral, evangelistic, apostolic, and teaching ministries particularly needed to equip the members for service, to build up the church to spiritual maturity, and to foster unity of the faith and knowledge of God. When members employ these spiritual gifts as faithful stewards of God's varied grace, the church is protected from the destructive influence of false doctrine, grows with a growth that is from God, and is built up in faith and love.--Fundamental Beliefs, 16.'

The Seventh-day Adventist Minister's Manual supports

this fundamental belief. The manual states that God through the agency of the Holy Spirit furnishes the church with needed spiritual gifts to carry out the commission given by Jesus. "Under this plan there is no hierarchy. Everyone is a minister performing some ministry for which he or she has been specially gifted."2 with this understanding the minister can view the church as a training school for Christian workers. "Its members should be taught how to

${ }^{1}$ Seventh-day Adventists Believe, 206.

${ }^{2}$ Seventh-day Adventist Minister's Manual (Silver Spring, MD: The Ministerial Association, General Conference of Seventh-day Adventists, 1992), 111. 
101

give Bible readings, how to conduct and teach.. . how to work for the unconverted." who is to conduct this training? The pastor.

The SDA Minister's Manual discourages pastors from monopolizing the work of the church and not viewing each member as also having a ministry. It is against the counsel of the SDA Church for its membership to see their obligation only as "pay, to pray and to obey." When this is the case, the work of the church is taken over by the clergy and "when a church is taken over by the clergy it grows cold." ${ }^{3}$ It is faulty for the pastors to approach the work of ministry with the assumption that "the role of church members is to help the professional ministers do their work, when in fact it is the function of the minister to help the people do their work. "14

Ellen White's comments concerning the duty of Seventhday Adventist ministers in relation to their work as it relates to equipping the members for ministry is strong and clear. ${ }^{5}$

The conclusion, then, is that the pastor must realize that one of the primary tasks of pastoring is to train,

\footnotetext{
'Ibid., 117.

I'Ibid., 112 .

${ }^{3}$ Ibid.

${ }^{4}$ Ibid.

${ }^{5}$ See the Appendix.
} 
equip, and empower the membership for ministry. Pastors are to create the vision, identify the gifts that God has placed within His church (Eph 4:7-12; 1 Cor 12:11) for the success of the gospel commission, then set out to train the members accordingly.'

\section{Community Leadership}

For Intentional Ministries to be used effectively in evangelizing the secular rich, the SDA pastor must also understand, accept, and be assertive about the pastor's role as a community leader. Pastors are viewed by the community as influential leaders. ${ }^{2}$ The pastor must be aware and alert to this perception and take the necessary steps to develop the skills, abilities, and relationship important for success in this area. The deliberateness on the part of the SDA clergy in this area is specifically important because

Adventist pastors in particular tend to be rather isolated from the city communities and neighborhoods in which they live. We feel we are busy with our own mission and upholding our own standards. The community often interprets this as unfriendly aloofness and spiritual snobbery. You ought to be as involved in community activities as your time and conscience allows. ${ }^{3}$

'Chapter 21 in the SDA Minister's Manual provides helpful suggestions on how best to pursue this area of vital responsibility. Materials are also available in abundance in the Andrews Sevent.h-day Adventist Theological Seminary that provide instructions in equipping the laity.

"Loretta Spivey, "What Color Is Worship?" Adventist Review, July 1996, 13 .

${ }^{3}$ SDA Minister's Manual, 30. 
Community involvement is important. It is only as the pastor becomes involved in the community that the influence of the church will be effective.

\section{Networking}

Involvement in the community and in civic affairs will provide opportunities the pastor will need to develop relationships with community leaders. The minister cannot leave the fostering of those relationships to chance. To effectively implement Intentional Ministries the pastor will have to be sensitive and deliberate in the fostering of relationships with other community leaders. Their influence will be needed to successfully implement the strategy.

Ray Bakke discusses at length, in his book the Urban Christian, the value of networking skills for ministry. He encourages the pastor within the community to develop networking with the business community, social agencies, and with other pastors.

According to Bakke, pastors need to "investigate their community resources in a systematic way." He further comments that pastors should not wait "until one of their members gets into difficulties before visiting the agency concerned, they are taking from the community's institutions and leaders and not investing anything in return." 2

\footnotetext{
'Bakke, 111.

${ }^{2}$ Ibid. , 115, 116 .
} 
Networking is very important because "once aware of the spiritual and social needs of an . . area... the pastor alone may feel helpless. . . This is where the importance of personal contacts comes in."1

\section{Creating Involvement}

As the minister has thoroughly revisited the understanding of the role and function of pastors as community leaders and equippers of the laity for ministry, the next challenge will be how to go about initiating Intentional Ministries.

A community rises as far as its leaders. The involvement and participation in community and civic affairs by the minister will serve as a model for the local congregation to emulate. The pastor, by example, influence, and instruction, fosters the spirit of community consciousness in the local congregation.

The pastor can lead the church to identify the concerns within the local community where the church functions. The next step would be to make these community concerns public. There are many possible ways for assembling community leaders, members of the upper class, and contributing members of the local SDA congregation.

The call to pursue initiatives for community development can be pursued through several avenues. The

\footnotetext{
'Ibid., 110.
} 
media, letters, or invitation is one such area. Members of the local congregation who are in contact with the upper classes or community leaders can be guided in utilizing their influence with these groups. Other avenues could be honoring services, local speaking events such as graduations, personal visitation, or under the auspices of an influential community leader with whom the minister has dialogue and who shares the concerns.

The pastor has to be sensitive concerning personal attitudes at these assemblies. The attendees have to be handled with careful regard and with an overriding sense of collegiality. The pastor's people and social skills must be carefully cultivated.

It is at these functions that the minister will have the opportunity to pledge the involvement of the church. The church can assist in providing facilities, funding, ideas, and solutions.' It is imperative that the various Intentional Ministries that are to be suggested as solutions for community development be seen as community-sponsored events and not as an SDA Event. It might be important to reiterate at this point that the goal is not to monopolize or take over these ministries, but to bring the two groups

\footnotetext{
${ }^{1}$ There are not many forums in the local communities with the facility, training orientation, ideas and ministries that are already existing within the local SDA church. The community-involved pastor would quickly be seen as an asset to such community-development gatherings and might be turned to for leadership and major involvement.
} 
together. The church will now be provided with the opportunity to work together with the community leaders and the upper classes for the development of the local community through the various Intentional Ministries. Staffing, funding, expertise, facilities, and training will be provided by the community and the church.

The function of Intentional Ministries is not to solve all the problems of the community. They function to address community needs, to bring the community together, to work towards solution and improvement, and also as a means of bringing the members of the community out of their isolation.

\section{Evangelistic opportunities}

Effective initiation of community-oriented Intentional Ministries is the "mingling" needed that will bring the church into contact with the upper class. This is the ultimate evangelistic purpose: to bring the upper-class community into contact with the SDA church community. The successful initiation and implementation of Intentional Ministries should achieve the purpose.

It is within these relational contexts that evangelism is to be pursued. The relationships that are established between the church members and the upper class cannot be viewed by the members as primarily social in nature, but evangelistic. These relationships are to provide opportunities for the SDA members to offer spiritual 
leadership. As Monte Sahlin puts it, the Christian is to demonstrate

caring and compassion through a genuine friendship that is unconditional, not conditioned by any behavior of the nonbeliever! I do not expect my unchurched friend to accept Christ or join the church because he or she may never do that, no matter how much I would like it. I do not expect my unchurched friend to do anything for my ego, my pocketbook or my career. I accept him as he is. ${ }^{1}$

Some relational opportunities that can be capitalized on in reaching out to the secular rich could be birthdays, anniversaries, marriages, hospitalization, sickness, death, family problems, and drugs. At these moments people are receptive and open. ${ }^{2}$

\section{Needed Skills}

What are the skills needed by the members of the SDA church to be meaningfully involved in this kind of evangelism?

\section{Relational}

SDA members who will be working for the evangelization of secular people have to be trained to take a different approach to evangelism than what they might be traditionally exposed to. They cannot view Intentional Ministry as an evangelistic campaign or program in the traditional sense. Intentional Ministries are not to be seen as a four- to six-

\footnotetext{
'Sahlin, 51.

${ }^{2}$ Samaan, 41 .
} 
week campaign, with doctrinal sermons being preached, appeals being made, and individuals being called to the altar to surrender their lives to Jesus, followed by a baptismal service.

with Intentional Ministries the evangelistic paradign shifts. The member must approach these Intentional Ministries with a dualistic mindset. First, this form of ministry is an honest, sincere effort on the part of the church to contribute to community building. While seeking to make its contribution to the community, the church will be working with members of the upper classes.

The second perspective is that the members will have to also view themselves as being involved not only in the traditional program-centered evangelism, but in lifestyle, relational-centered evangelism. Rebecca Pippert attempts an explanation of this kind of evangelism.

Jesus wants to heal our sight. He wants us to see that the neighbor next door or the people sitting next to us on a plane or in a classroom are not interruptions to our schedule. They are there by divine appointment. Jesus wants us to see their needs, their loneliness, their longings, and he wants to give us the courage to reach out to them. If we are to do that we need to do two things: we will have to take risks as well as get beneath the surface of people's lives.

To take initiative opens us up to the risk of rejection. To let people into our lives is a frightening but essential ingredient in evangelism.' Seventh-day Adventists who will be involved in using Intentional Ministries as a medium to reach the upper class

'Rebecca Manley Pippert, out of the Salt Shaker (Wheaton, IL: InterVarsity Press, 1979), 114. 
need to view evangelism, witnessing, reaching people for Jesus and soul-winning as a lifestyle and not a duty, job, or program. "The Christian must be the one who loves, cares and listens first." "I

People skills, social skills, relational skills, and communication skills are necessary to effectively participate in Intentional Ministries.

How many countless opportunities we miss by not taking the initiative, by not sharing a genuine smile, a firm handshake, an affirming word, a prayer. No one should ever underestimate such small and sincere gestures. They often open wide doors of witnessing opportunities. ${ }^{2}$

Ellen White reinforces the point: "Christian sociability is altogether too little cultivated by God's people. . . Especially should those who have tasted the love of Christ develop their social powers, for in this way they may win souls to the Saviour." 3 She further admonishes us "not to renounce social communion. We should not seclude ourselves from others. . . Social power . . must be improved in winning souls to the Saviour."4

It is absolutely necessary to reiterate that the members cannot view their non-SDA associates as targets to

'Ibid., 124 (emphasis mine).

${ }^{2}$ Samaan, 48,49 .

${ }^{3}$ Ellen G. White, Testimonies to the Church, vol. 6 (Mountain View, CA: Pacific Press Pub. Assn., 1948), 172.

${ }^{4}$ Ellen G. White, The Desire of Ages (Mountain View, CA: Pacific Press Pub. Assn., 1940), 152 . 
be reached. They must see them first and only as they really are, people--people with "their needs, their longings, their loneliness,"l and people functioning with all the challenges, joys, and opportunities of humanity. The members will have to lead the initiative to establish, build, and nurture relationships. Wayne MCDill refers to the failure to build relationship in witnessing by many Christians as the missing ingredient in much of today's evangelism. He further comments, "Evangelism will be effective to the extent that it depends on the establishment and cultivation of meaningful relationships."2 This is what this report labels as lifestyle evangelism.

Relational evangelism . . . is a matter of trust and credibility, a matter of responsibility; a willingness to pay the high price of personal involvement, of emotional will, the price of love. In the day of identity crisis, the personalization and anonymity, a weary world waits for someone with good news who cares. ${ }^{3}$

It is within relationships established by the church and the upper-class community that witnessing will take place.

The SDA member must consciously and deliberately at all times, in a natural, sincere manner, demonstrate that Jesus' ethics and teachings are the governing and motivational

'Wayne McDill, Making Friends for Christ (Nashville, TN: Broadman Press, 1979), 14.

${ }^{2}$ Ibid. , 15 .

${ }^{3}$ Ibid. 
force behind that member's attitude and behavior. This can be seen as lifestyle evangelism.

Philip Samaan is right when he writes,

No matter who we are, or what our background is, we all share the same fundamental needs. At the very core of our being each of us has the universal need to accept and be accepted, to love and to be loved, to trust and be trusted, to be free and to be fulfilled.'

Through relationships, the Christian can minister to and share in the people needs of the upper class.

The church must come to see the upper-class community not as "upper class people," but as people. The value of this cannot be understated. The fact that the upper class are people is all the reason a Christian needs in taking the initiative to establish and build meaningful relationships. Samaan puts it this way: "The biggest reason for taking the initiative is simply because they are people. That is why Jesus came into this world. People are His most important program, not because of their status or accomplishments, but because they are valuable just in themselves."

\section{Listening}

While listening skills should be classified in the general relational skills, the import of it is so significant that it merits being discussed separately. For the members or pastors involved in Intentional Ministries as

\footnotetext{
'Samaan, 72 .

${ }^{2}$ Ibid. , 46.
} 
an approach to make contact with the upper classes, they have to develop the art of listening.

Listening skills are the key to this approach. When a church member really listens to another person, he is demonstrating his care about the other person's opinions, feelings, and values. Disciplined listening embodies unselfish love and compassion at a practical level. It also helps to uncover the felt needs of the non believer and paves the way for an appropriate verbal witness, even to those usually resistant to religion.'

Sahlin goes on to say that

such listening skills as "active questioning," how to check out the feelings of another person, and "story listening" can be taught in a few hours of simple workshops in which church members enjoy the fellowship as they practice on one another. These are basic life skills that can improve family communication as well as help in relating to unbelievers in the secular context of work, neighborhood and community service. ${ }^{2}$

\section{Civic Consciousness}

A strong sense of community and community contribution is another indispensable attribute for those planning to utilize this strategy. Community consciousness and community pride must be fostered. Involved SDAs must view themselves as a contributing part of the community and be willing to see how, as Christians, they can contribute to the building and development of their community. community responsibility, when properly articulated, should resonate with responsible citizens such as christians. Christians must take civic responsibility within the community in which

'Sahlin, 51 .

${ }^{2}$ Ibid. 
they live. "Taking personal responsibility is important in a society where blame always belongs to the next person. - . Leadership is still best done by example."l What Jim wallis declares of the church, when he wrote "We need religious leaders known for their service instead of their fundraising," 2 is to be applied to the general church. The church is a leader in the community and must rise to its responsibility.

\section{Summary}

The purpose of the approach suggested by this dissertation is to bring the church and the upper classes into contact. Presently there is a state of isolation and insulation existing between the two groups. The careful implementation of Intentional Ministries will be the bridge needed by the church to establish contact with the upper classes.

Why Intentional Ministries? As has been demonstrated, Intentional Ministries are social programs utilized by the church to make an impact on the community. It is the church's method towards taking an active approach towards addressing social problems being faced in the community. The upper classes are always interested in the social health of the community in which they live. If they are properly

\footnotetext{
'Jim Wallis, The Soul of Politics (New York: Harcourt, Brace \& Co., 1995), 246, 247.

${ }^{2}$ Ibid., 246 .
} 
contacted by the church to help develop various initiatives to improve the local communities, they will lend their support and influence. This union between the church and the upper classes will provide the opportunity the church needs to establish contact with the upper classes that can make evangelization possible.

The traditional approach to evangelism will not be effective in working with the upper classes. The type of evangelism that will be effective is lifestyle and relational evangelism. The members of the church who have formed working unions with the upper classes will now lead out in developing relationships. From these relationships they will seek opportunities to provide spiritual leadership.

For the approach to be effective, the SDA minister must be clear, comfortable, and assertive with the role of community leader and an equipper of the members of the church. If the minister can

awaken and unleash the massive talent, resources, creativity, and energy lying dormant in the typical local church, Christianity will explode with growth at an unprecedented rate. The greatest need in evangelical churches is the release of the members for ministry. ${ }^{1}$

'Warren, 365. 


\section{CHAPTER 5}

SUMMARY, RECOMMENDATIONS, AND CONCLUSIONS

\section{Summary}

This dissertation has reported that the Seventh-day Adventist Church in Jamaica over the past 107 years has grown from a small beginning into a powerful movement of 162,851 members by 1995 . These members are organized into three conferences. There are seven high schools, one hospital, and four clinics operated by the church. The population of Jamaica in 1995 was $2,500,000$; this means that one in every fifteen Jamaicans is a Seventh-day Adventist.

In Jamaica there are three major classes of people: the low, middle, and upper classes. These are further subdivided into nine classes: the lower-lower, middle-lower and upper-lower; lower-middle, middle-middle, and uppermiddle; lower-upper, middle-upper, and upper-upper classes. The church in Jamaica has been effective in reaching the upper-lower and the lower-middle and, to a lesser extent, the middle-middle classes. The upper classes are not being reached by the church.

Various factors contribute to the inability of the church to reach this group, but one of the most outstanding 
is the traditional method of evangelism used by the church to win converts. The church has effectively used evangelistic crusades, and specifically tent evangelism, to win many of its converts. Tent evangelism, while very effective in reaching the upper poor and the lower-middle, has been ineffective in reaching the upper-middle and the upper classes.

This dissertation suggested Intentional Ministries as a method that can be used by the Seventh-day Adventist Church in Jamaica to make contact with the upper classes. These contacts will make it possible for lifestyle evangelism, personal evangelism, and other forms of relational evangelism to be creatively utilized by trained Seventh-day Adventist members towards converting people to the SDA message within the upper classes.

Intentional Ministries is any ministry, program, or agency that is created, designed, or organized by the church to make a social difference within the communities where there are SDA churches. There are a plethora of social problems existing in many of these communities. These problems are destructive to the health of the communities and, by extension, the nation. Members of the upper classes are concerned about these social problems. They have tried in the past, working in association with governmental social programs, to address these community problems, but have met with repeated failure in many cases. 
This dissertation is suggesting that the church, already having a legitimate concern for the social problems within the communities," can take the leadership in initiating creative programs to address these social problems. The church would approach the community, especially members of the upper classes, with proposals to implement programs that will enhance the well-being and health of the community. The church, working along with community leaders and members of the upper classes, would implement these social programs (Intentional Ministries) within the communities.

The union between the two groups would make possible opportunities that the church needs to use various forms of personal and relational evangelism to convert people within the upper-class community.

\section{Caveat}

It should be noted, however, that establishing contact with the upper classes does not mean that they will automatically be converted to the SDA message. Deliberate, careful evangelism will have to be pursued after the contact is established. The purpose of Intentional Ministries is to provide the church with possible avenues to bridge the isolation between the church and the upper classes so that evangelism can begin.

'Jas 2:15-17; Matt 25:34-36. 
It should also be noted that materialism and secularization have historically been stubborn barriers to evangelization. Contact between both groups will not be all that will be needed to allow for conversion. But nothing can begin without contact.

While these community initiatives can provide contact between the upper classes and the church, it is not the purpose of this dissertation to suggest community initiatives as the only medium by which contact can be pursued. There are other avenues available to the church that can be utilized as means for establishing evangelistic contact with the upper classes. The church in Jamaica could study to see how it can take advantage of West Indies College, the high schools, the hospital, and the clinics as mediums for bridging the isolation and insularity between itself and the upper classes.

\section{Recommendations}

The Conference

Nancy Adler argues, in her book organizational Behaviour, that the direction an organization takes, and how it functions and what is emphasized as success to a large degree is determined by the leadership.' In order for Intentional Ministries to be effective as a method of reaching the upper classes, it has to be supported by the

\footnotetext{
${ }^{\mathrm{I} A d l e r,} 147$.
} 
conference. It has been my experience as a pastor in Jamaica that programs not personally promoted, emphasized, and supported by the conference president are neglected by the pastors and the churches. It is vital to the success of Intentional Ministries that the conference president own the program and have it voted as a legitimate program within the conference. After this is done there are three areas that need to be addressed by the conference committee. These areas are: (1) the role of the community Service leaders, (2) the tenure of pastorates, and (3) the evaluation tools.

Community service leaders. The role, duties, and function of the Community Service organization needs to be expanded. Presently the community service is a sub-division of the Lay Activities Department. The impression given by the SDA Church Manual is that the Community Service leader is someone appointed by the Lay Activity Council of the local church to direct only the community service center.' The conference would need to expand and assert the role of the Community service.

1. The Community service Department must be designed to make an impact within the local communities, the secular environment, the nation at large. This office must be organized to live out the meaning of its name: social

\footnotetext{
'Seventh-day Adventist Church Manual (Hagerstown, MD: Review and Herald Pub. Assn., 1995), 90.
} 
services to the community or services within the community provided by the SDA church.

2. The Community Service Coordinator within the conference would be responsible for assisting local pastors in organizing Intentional Ministries within the local communities and training local community Service leaders for leadership in Intentional Ministries.

3. The concern of the Community Service coordinator must be the supervision of the organization of Intentional Ministries. Only as an Intentional Ministry is organized within a local pastoral district can success or progress be affirmed.

4. This department must have all the cooperation of the Pathfinders, Youth, Education, Health and Temperance, and Family Ministries Departments in organizing various Intentional Ministries relevant in relation to these departments.

Pastoral tenures. It has been my experience from observing the conferences in Jamaica for the past sixteen years that pastors are moved every three to five years. This practice is inimical to church growth of any form and especially for Intentional Ministries. Pastors need time to "carry out a consistent program over the years, [that are] single-mindedly dedicated to church growth."I

'McGavran, Understanding Church Growth, 142 . 
Intentional Ministries will take time to develop. It will take time for the pastor to develop a community network; it will take time to facilitate the implementation of the programs, and it will take time to train the members for Intentional Ministries. Dr. Kent R. Hunter, president of the Church Growth Center in Corunna, Indiana, strongly advises against frequent pastoral changes. He writes,

A church that changes pastors every few years can at least be guaranteed that it will never have any longterm goals. . . . Many pastors leave a church before they reach their peak of effectiveness. For most pastors, the effectiveness of their leadership increases as years go by. ${ }^{1}$

It would be necessary for the conference to facilitate the practice of having longer pastorates if it hopes to mature a church and move forward with Intentional Ministries. The practice of moving pastors frequently "generally is counterproductive."2

The evaluation tools. Pastors' quarterly workers' reports function as a type of evaluation of the pastor and also an indirect job description index. At the pastors' meeting I attended in Jamaica, the only report that was asked of me was how many persons I had baptized at the end of each quarter. At the year-end pastors' meetings, the only request that was made concerning my goal for the year

\footnotetext{
${ }^{1}$ Kent R. Hunter, Moving the church into Action (St. Louis: Concordia Publishing House, 1989), 102.

${ }^{2}$ Ibid.
} 
was how many I hoped to baptize. Sometimes these reports are published along with tithe increases (or decreases) over the year. The impression conveyed to the pastor is that as long as baptismal goals are reached and the tithe grows, then the task of ministry is being accomplished. A pastor, therefore, organizes crusades and sets out to baptize as many people as possible. The other areas of the church's growth and development are left to the integrity, interests, . and personal concerns of the pastor or other lay leaders. For Intentional Ministries to be effective, the conference has to develop methods of incorporating it in the workers' reports.

Workers' reports serve as a method of evaluation.' Ministers who do not reach their baptismal goals often feel inadequate and as having failed in the eyes of their colleagues. No wonder this and any other instrument of evaluation "produces more negative than positive feelings in an employee." 2 These traditional instruments of evaluation used by the conference have little to do with a worker's development or learning. ${ }^{3}$ Evaluation of the pastor's ministry needs to be broadened. Evaluation instruments must challenge the workers to expand their ministry beyond tithe

${ }^{1}$ Leslie Pollard and Prudence Pollard, "Ministerial Evaluation: Pitfalls and Opportunities," Ministry, August 1996,6 .

${ }^{2}$ Ibid., 7 .

${ }^{3}$ Ibid. 
increases and baptisms (as vital as these areas are). They must be designed to function as a "positive instrument for learning and achieving the mission of the ministry."1

Along with challenging the minister to broaden his or her ministerial activities, evaluation instruments must "convey accurate information about the ability and the activity of the ministerial worker." 2 Pastors would be challenged to get involved in Intentional Ministries if at the end of each quarter a report is requested on the progress of these ministries.

\section{The Pastor}

1. The pastor must develop his ability as an integral, active, and functioning member of the community where the church is located. The image of "Adventists in general and the Adventist pastor in particular" ${ }^{3}$ living in isolation from the community and the neighborhood must be changed. This can be changed only when the pastor becomes assertive as a community leader in activities that are noticeable by the community.

Pastors must see ministry beyond crusades and tithe increases. The pastor must also view community leadership as ministry.

\footnotetext{
${ }^{1}$ Ibid.

${ }^{2}$ Ibid. , 5.

${ }^{3}$ Seventh-day Adventist Minister's Manual, 30.
} 
2. Bakke writes, "Cities are torn by race, class and constitutional structures. . . We desperately need pastors who commit a significant part of their energy to the networking and building up [of their communities]."1 Networking is important if the minister is to effectively become a community leader and implement Intentional Ministries. Relationships must be developed with the business community, other clergy, community leaders, and members of the upper classes.

3. Intentional Ministries are not to replace traditional evangelism. This is not a case of "either/or," rather it is a situation involving "both/and." Traditional forms of evangelism have been effective in winning other social classes within the community; they must be retained, which is why Intentional Ministries are created.

4. Stephen R. Covey, in his book The 7 Habits of Highly Effective People, identified "Principles of Balanced Self-Renewal" as one of those habits. These principles are discussed in chapter 7 entitled "Sharpen the Saw." 2 In this chapter it is discovered that effective leaders find time for rest, recreation and exercise. Covey said: "Most of us think we don't have enough time to exercise. What a

'Bakke, 113.

${ }^{2}$ Stephen R. Covey, The 7 Habits of Highly Effective People (New York: Simon \& Schuster Publishing, 1989), 287. 
distorted paradigm! We don't have time not to."I The pastor must take time for rest, exercise, or any other renewal activity. "Too many Adventist ministers preach against addiction while they themselves are being addicted-to work. If you are proud of overwork, you may well have both an ego problem and a theological one."2

Working with Intentional Ministries and working with the church can be highly stressful. In fact, general "pastoring is stressful because it is a people-centered occupation, and people cause stress." ${ }^{3}$ The pastor, in order to experience "renewal"4 and to avoid burnout, needs various recreational activities, especially those that result in the formation of friendships or joining a support group.5

Networking can result in renewal advantages for the pastor. Careful formation of professional associations can become pleasant diversions and aid in preventing burnout. Isolation and loneliness are some of the basic causes of burnout, 6 but having a sense of "community and support" is what David Claerbaut calls "antidotes to burnout."?

'Ibid., 289.

${ }^{2}$ Seventh-Day Adventist Ministers' Manual, 36.

${ }^{3}$ Ibid.

${ }^{4}$ Covey, 288 .

'Seventh-day Adventist Ministers' Manual, 37.

${ }^{6}$ Claerbaut, 206.

${ }^{7}$ Ibid., 207. 
Personal renewal cannot be overemphasized. As the pastor interacts with people, he or she needs to keep "lighthearted and joyous."' claerbaut advises that for a minister to survive, one of the traits that must be developed is "a sense of humor." The pastor has to learn to "laugh and appreciate the delightful yet frustrating incomprehensibility of life. Laughter is a therapeutic gift, and finding as many ways as possible to exploit its use will be in the best interest of the . . pastor."2

5. It is very important that the pastor take advantage of the mass media. ${ }^{3}$ This will serve the implementation of Intentional Ministries in two major areas: (a) the media can be used to create awareness and build consensus for a social need within the community; (b) to give public recognition for those who are participating in Intentional Ministries, especially community leaders and those within the upper class. This form of public recognition is very important to people of wealth and influence.

6. In the selection of the Community Service leader the pastor has to take a central interest. This cannot be left to chance. The pastor must provide leadership as to the qualifications that are needed for a Community Service

'White, Ministry of Healing, 488.

${ }^{2}$ Claerbaut, 202, 203.

${ }^{3}$ Donald K. Smith, Creating Understanding (Grand Rapids, MI: Zondervan Publishing House, 1992), 177. 
leader who would serve as an administrative assistant to the pastors in the organization, implementation, and supervision of Intentional Ministries.

\section{The Church}

1. The Community Services Department, as it is discussed in the SDA Church Manual, is too limited in its scope to effectively implement Intentional Ministries.' The local church will have to discuss and vote at its local board meeting a broadening of the job description and function of this office.

The goal of the Community Service leader would now include creative ways to organize the church to achieve an impact on the community. It would now be the function of the Community Service leader to study the social needs of the community and to study the various resources of the church and the community to see how these can be utilized in the implementation of Intentional Ministries.

2. It would be ideal to choose a person within the congregation who is already a community leader. This person could be a successful businessman, a school principal, a high profile professional, or someone who carries a considerable amount of community influence. This influence could be formal or informal.

'See pp. $88,90$. 
3. Working in Intentional Ministries is not possible for every member.' Along with being trained and having a sense of calling to work for the conversion of the upper classes, other characteristics are needed. Some of these characteristics are: (a) a sense of confidence that comes from education, intelligence, or giftedness within this area; (b) a spirit of creativity and perseverance; (c) genuine concern for the social problems in the community; (d) strong people and communication skills; and (e) a strong sense of evangelism.

4. The evangelistic focus of Intentional Ministries must not be lost. Associations formed with the upper classes are not to be exploited for personal benefit. ${ }^{2}$ The upper classes are used to this kind of manipulation and will be looking for it. ${ }^{3}$ The goal in the formation of associations between members of the church and the upper classes is to take advantage of opportunities to share the gospel.

5. The type of evangelism that will be appropriate with the upper classes after the relationships are established are lifestyle or relational evangelism. This will be person-to-person evangelism since this type of evangelism is very effective. "The reason is simple: it is

\footnotetext{
'Sevebth-day Adventist Minister's Manual, 112.

${ }^{2}$ Sahlin, 51 .

3Mckinney, interview, February 1996.
} 
personal evangelism, the sharing of the gospel between two friends. This is the most natural thing in the world."1

6. The church should be open to change. "For any congregation that is at all settled, change is one of the hardest things to face. And yet it is a prime necessity."2 The church will have to be open to change in two primary areas. First, the local church is accustomed to using crusades as a means of evangelism; it will be difficult to conceive of Intentional Ministries as evangelism. There probably will not be any baptisms after six weeks. This is not an index of failure. This is a different form of evangelism.

The second area of change has to do with SDA traditional worship. In some cases it might be attractive to the incoming upper-class members, and in other cases it might be unattractive. It might be necessary in some cases to make changes. Also, upper-class people, for the most part, are highly educated, well travelled, and at times very assertive. It is possible that when they become committed members, they might bring a different kind of approach to the church's life and worship. Dialogue and not resistance will need to be the posture of the congregation.

'Michael Green, Evangelism Through the Local Church (Nashville, TN: Thomas Nelson Publishers, 1992), 259.

${ }^{2}$ Ibid. , 89 . 


\section{Conclusion}

"God calls for workers to reach those of the higher classes, who, if converted, could in turn work for those of their own standing. He desires to see converted talent and converted influence enlisted in his work." 1 Many of the higher classes are secularized and unchurched. They are neglected by the church since most evangelistic activities are not designed to reach them. Even professional churchgrowth leaders view this class as difficult to win ${ }^{2}$ and advise that attention be focused on those who are "winnable." While I understand the background and perspective of McGavran, I disagree with his conclusion that the upper classes need to be won as any other class of people. And in Jamaica no mission has ever been designed to reach this class. This must change.

There are non-SDA church groups, however, who have been making advances in attracting members of the upper class to God. ${ }^{4}$ These groups have demonstrated that people within the upper classes have spiritual needs like people everywhere. Many of these churches that are effective in reaching this group have departed from the traditional method of

\footnotetext{
${ }^{1}$ White, Evangelism, 554.

'McGavran, Understanding Church Growth, 204.

${ }^{3}$ Ibid., 206-208.

4Warren, 41.
} 
evangelism. ${ }^{1}$ New and creative methods that are different from those that are needed to attract upper-class people have been effective in attracting the lower classes. Intentional Ministries can be a creative method of evangelism that can be used by the Seventh-day Adventist Church to attract the upper classes. It is my conviction that if Intentional Ministries are carefully implemented through the local churches, they will successfully attract the upper classes.

Intentional Ministries closely follows one of the methods used by Jesus. "Jesus loved lost people and loved spending time with them. . . It is obvious from the Gospels that Jesus enjoyed being with seekers more than being with religious leaders." 2 Rick warren writes that "loving unbelievers the way Jesus did is the most overlooked key to growing a church." ${ }^{3}$

Intentional Ministries demonstrate love for people and their needs, they show love for the community, love for all classes, and they reach out in love to the upper classes with the hope of making contact that can ultimately result in the upper classes being converted to Jesus Christ.

"Jesus attracted crowds by meeting peoples' needs. Jesus often met a felt need in order to establish a

\footnotetext{
'Ibid., chapter 11.

${ }^{2}$ Ibid., 208 .

${ }^{3}$ Ibid.
} 


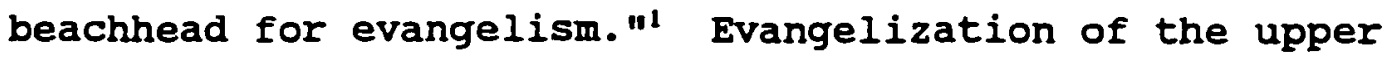
classes is the ultimate goal of Intentional Ministries. While meeting the social needs of the community, in partnership with the upper classes, Intentional Ministries will be meeting the spiritual needs of the upper classes. This class of people need Jesus. They need the Gospel. They need to hear the SDA message. Intentional Ministries can be the method needed to get the attention of the upper classes so they can hear the good news of salvation as preached by the Seventh-day Adventist Church and be converted. ${ }^{2}$

'Ibid., 219.

${ }^{2}$ Ibid. 
APPENDIX

Reproduced with permission of the copyright owner. Further reproduction prohibited without permission. 


\section{THE DUTY OF THE MINISTER \\ AND THE PEOPLE}

God has given to "every man his work." He has not left the spiritual interests of the church wholly in the hands of the minister. It is not for the good of the minister, nor for the good of the individual members of the church, that the minister should undertake exclusive charge of the Lord's heritage. Each nember of the church has a part to act in order that the body may be preserved in a healthful condition. We are all members of the same body, and each member must act a part for the benefit of all the others. All members have not the same office. As the members of our natural body are directed by the head, so as members of the spiritual body, we should submit ourselves to the direction of Christ, the living head of the church. We are as branches of a common vine. Christ speaks of us as branches that have been grafted into himself, the True Vine. If we are true believers, living in daily, hourly connection with Christ, we shall be sanctified through the truth, and shall act our part in blessed union with the other branches of the True Vine ("The Duty of the Minister and the People).

The minister and the church-members are to unite as one person in laboring for the up-building and prosperity of the church. Every one who is a true soldier in the army of the Lord will be an earnest, sincere, efficient worker, laboring to advance the interests of Christ's kingdom. Let no one presume to say to a brother who is walking circumspectly, "You are not to do the work of the Lord; leave it for the minister." Many members of the church have been deprived of the experience which they should have had, because the sentiment has prevailed that the minister should do all the work and bear all the burdens. Either the burdens have been crowded upon the minister, or he has assumed those duties that should have been performed by the members of the church. Ministers should take the officers and members of the church into their confidence, and teach them how to labor for the Master. Thus the minister will not have to perform all the labor himself, and at the same time the church will receive greater benefit than if he endeavored to do all the work, and release the members of the church from acting the part which the Lord designed that they should ("The Duty of the Minister and the People).

All through our ranks, individual talent has been sadly neglected. A few persons have been selected as spiritual burden-bearers, and the talent of other members has remained undeveloped. Many have grown weaker since their union with the church, because they have bee practically prohibited from exercising their talents. The burden of church work should be distributed among its individual members, so that 
each one may become an intelligent laborer for God. There is altogether too much unused force in our churches. There are a few who devise, plan, and work; but the great mass of the people do not lift their hands to do anything for fear of being repulsed, for fear that others will regard them as out of their place. Many have willing hands and hearts, but they are discouraged from putting their energies into the work. They are criticised if they try to do anything, and finally allow their talents to lie dormant for fear of criticism, when if they were encouraged to use them, but work would be advanced, and workers would be added to the force of missionaries. The wisdom to adapt ourselves to peculiar situations, the strength to act in time of emergency, are acquired by putting to use the talents the Lord has given us, and by gaining an experience through personal work. A few are selected to hold responsible positions, and the work is divided up among these brethren. Many more who ought to have an opportunity to develop into efficient workers for the Lord, are left in the shadow.

Many of those who stand in places of trust, cherish a spirit of caution, a fear that some move may be made which is not in perfect harmony with their own methods of labor. They require that every plan should reflect their own

personality. They fear to trust another's methods. And why are they not to be trusted? ("The Duty of the Minister and the People").

Because they have not been educated; because their leaders have not drilled them as soldiers should be drilled. Scores of men should be prepared to spring into action at a moment's warning, should an emergency occur which demanded their help. Instead of this, the people go to church, listen to the sermon, pay their tithes, make their offerings, and do very little else. And the benefit of their advice and counsel in planning and their help in executing the plans that they have had a part in forming ("The Duty of the Minister and the People").

There are to be no secret societies in our churches. "All ye are brethren." The minister's work is the lay member's work as well. Heart should be bound to heart. Let all press forward, shoulder to shoulder. Is not every true follower of christ open to receive his teachings. And should not all have an opportunity to learn of Christ's methods by practical experience? Why not put them to work visiting the sick and assisting in other ways, and thus keep the church in a workable condition? All would thus be kept in close touch with the minister's plans, so that he could call for their assistance at any moment, and they would be able to labor intelligently with him. All should be laborers together with God, and then the minister can feel that he has helpers in whom it is safe to trust. The 
minister can hasten this desirable end by showing that he has confidence in the workers by setting them to work ("The Duty of the Minister and the People").

Who is to blame for the deficiency in the churches? Who is to be censured because willing hands and zealous hearts have not been educated to labor in a humble way for the Master? There is much undeveloped talent among us. Many individuals might be laboring in towns and cities, visiting from house to house, becoming acquainted with families, entering into their social life, dining at their tables, entering into conversation by their firesides, dropping the precious seeds of truth all along the Iine. As they exercise their talents, Christ will give them wisdom, and many believers will be found rejoicing in the knowledge of the truth as a result of their labors. Thousands might be getting a practical education in the work by this personal labor ("The Duty of the Minister and the People").

Neither Conference officer nor minister has a call from God to indulge distrust of God's power to use every individual who is considering a worthy member of the church. This cautiousness, so-called, is retarding almost every line of the Lord's work. God can and will use those who have not had a thorough education in the schools of men. A doubt of his power to do this is manifest unbelief; it is limiting the Omnipotent power of the one with whom nothing is impossible. 0 for less of this unsanctified, distrustful caution! It leaves so many forces of the church unused; it closes up the way so that the Holy spirit cannot use men; it keeps in idleness those who are willing and anxious to labor in Christ's lines; it discourages many from entering the work who would become efficient laborers together with God if they were given a fair chance. Those who would be laborers, who see the great necessity for consecrated workers in the church and in the world, should seek strength in the secret places of prayer. They should go forth to labor, and God will bless them, and make them a blessing to others. Such members would give strength and stability to the church. It is the lack of spiritual exercise that makes church-members so weak and inefficient; but again I would ask, Who is to blame for the state of things that now exists? ("The Duty of the Minister and the People")."

\footnotetext{
'Ellen G. White, "The Duty of the Minister and the People," Advent Review and Sabbath Herald, July 9, 1895.
} 


\section{BIBLIOGRAPHY}

Reproduced with permission of the copyright owner. Further reproduction prohibited without permission. 


\section{BIBLIOGRAPHY}

Adler, Nancy J. Organizational Behavior. Boston, MA: PWSKent Publishing Co., 1991.

Bakan, Abigail A. Ideology and Class Conflict in Jamaica. Montreal, Quebec: McGill-Queen University Press, 1990.

Bakke, Ray. The Urban Christian. Downers Grove, IL:

Bell, Wendell. Jamaican Leaders. Los Angeles, CA: University of California Press, 1964.

Berquo, Elza, and Peter Xenos, eds. Family systems and Cultural Change. New York: oxford University Press, 1992 .

Black, Clinton V. The Story of Jamaica. London: Collins Clear Type Press, 1965.

Brown, Aggrey. Color, Class and Politics in Jamaica. New Brunswick, NJ: Transaction Books, 1979.

Bryan, Patrick E. Philanthropy and Social Welfare in Jamaica. Kingston, Jamaica: Institute of Social and Economic Research, 1990.

Carter, Stephen. The Culture of Disbelief. New York: Harper Collins Publishers, 1993.

Chevannes, Barry. Rastafari: Roots and Ideology. New York: Syracuse University Press, 1995. - The Case of Jah vs. Middle Class Society: Rastafari Exorcism of the Ideology of Racism in Jamaica. The Hague, Netherlands: Institute of Social Studies, 1989.

Claerbaut, David. Urban Ministry. Grand Rapids, MI: Zondervan Publishing House, 1983.

Covey, Stephen R. The 7 Habits of Highly Successful People. New York: Simon \& Schuster Pub., 1989. 
Davis, Edmund. Roots and Blossoms. Barbados: Cedar Press, 1977 .

Dulles, Avery. Models of the Church. New York: Doubleday Publishers, 1987.

The Gleaner Geography and History of Jamaica. Kingston, Jamaica: Gleaner Company, 1995.

Goodman, Norman. Introduction to Sociology. New York: Harper Perennial Publishers, 1992.

Green, Michael. Evangelism Through the Local Church. Nashville, TN: Thomas Nelson Publishers, 1992.

Hunter, George G., III How to Reach Secular People. Nashville, TN: Abingdon Press, 1992.

Hunter, Kent R. Moving the Church into Action. St. Louis, MO: Concordia Publishing House, 1989.

Ingram, K. E. Jamaica World Bibliographical Series. Vol. 45. Oxford, England: Clio Press, 1984.

Johnson, Paul. The Quest for God. New York: Harper Collins Publishers, 1996.

Joseph, Lynette, and Derek Gordon. The Middle class in Jamaica: A Quantitative and Qualitative study of the Characteristics of Its Members, Changes in Their Composition and Strateqies Adopted to Deal with the Econonic Crisis. Kingston, Jamaica: Documentation and Data Canter, University of West Indies.

Kaplan, Irving, et al. Area Handbook for Jamaica. Washington, DC: American Press, 1976.

Le Joly, Edward, S.J. Mother Teresa of Calcutta. San Francisco: Harper Row Publishers, 1993.

Lewis, Rupert. Jamaica's struggle in the Periphery. London: Writers and Readers Publishing Cooperative Society, 1982..

- Marcus Garvey: His Work and Impact. London: Collins Clear Type Press, 1972.

Manley, Michael. The Politics of Change. London: Andre Deutsch, 1974 . 
- Jamaica's struggle in the Periphery. London: Writers and Readers Publishing Cooperative society, 1982 .

McDill, Wayne. Making Friends for Christ. Nashville, TN: Broadman Press, 1979.

McGavran, Donald. Church Growth in Jamaica. India: Luckman Publishing House, 1962.

- Understanding Church Growth. Grand Rapids, MI: Eerdmans Publishing Company, 1990.

Miller, Errol. Jamaican Society and High Schooling. Kingston, Jamaica: Institute of Social and Economic Research, 1990.

Nettleford, Rex. Mirror, Mirror. Kingston, Jamaica: Williams, Collins and Sangster Press, 1971.

Paulien, Jon. Present Truth in the Real World. Boise, ID: Pacific Press Pub. Assn., 1993.

Peterson, Eugene H. The Message. Colorado Springs, CO: NavPress, 1993.

Pippert, Rebecca Manley. Out of the Salt Shaker. Wheaton, IL: Intervarsity Press, 1979.

Pollard, Leslie, and Prudence Pollard. "Ministerial Evaluation: Pitfalls and opportunities." Ministry, August 1996,6 .

Porter, David. Mother Theresa: The Early Years. Grand Rapids, MI: Eerdmans Publishing Co., 1986.

Sahlin, Monte. Sharing our Faith with Friends without Losing Either. Washington, DC: Review and Herald Pub. Assn., 1990.

Samaan, Philip G. Christ's Way of Reaching People. Hagerstown, MD: Review and Herald, 1990.

Schaller, Lyle A. The Change Agent. Nashville, TN: Abindgon Press, 1972 .

Serrou, Robert. Theresa of Calcutta. New York: McGrawHill Book Company, 1980.

Seventh-day Adventists Believe: 27 Fundamentals. Hagerstown, MD: Review and Herald Pub. Assn., 1987. 
Seventh-day Adventist Church Manual. Hagerstown, MD: Review and Herald Pub. Assn., 1995.

Seventh-day Adventist Encyclopedia. Washington, DC: Review and Herald Pub. Assn., 1976.

Seventh-day Adventist Minister's Manual. Silver Spring, MD: Ministerial Association, General Conference of SDA, 1992 .

Seventh-day Adventist Student's Source Book. Washington, DC: Review and Herald Pub. Assn., 1962.

Seventh-day Adventist Yearbook. Hagerstown, MD: Review and Herald Pub. Assn., 1904, 1995, 1996.

Smelser, Neil J. Sociology. Englewood Cliffs, NJ: Prentice-Hall, 1981.

Smith, Donald K. Creating Understanding. Grand Rapids, MI: Zondervan Publishing House, 1992.

Smith, M. G. Poverty and Wealth in Jamaica. Kingston, Jamaica: Institute of Social and Economic Research, University of West Indies, 1989.

Spivey, Loretta. "What Color Is Worship?" Adventist Review, July 1996, 13.

Stafford, Earle. The Basic Jamaica Book. Ontario, Canada: ECI Publications, 1977.

Stone, Carl. Class, Race and Political Behavior in Urban Jamaica. Kingston, Jamaica: Institute of Social and Economic Research, UWI, 1973.

Stone, Rosemarie. The stone columns. Kingston, Jamaica: Sangster Book Stores, 1994 .

stott, John R. W. Christian Mission in the Modern World. Downers Grove, IL: InterVarsity Press, 1975.

Strobel, Lee. Inside the Mind of Unchurched Harry and Sally. Grand Rapids, MI: Zondervan Publishing House, 1993.

Thompson, Winston A. "Reggae Music: An Effective Epistemology." Union Seminary Ouarterly Review 36, no. 4 (Summer 1981): 264 .

Wallis, Tim. The Soul of Politics. New York: Harcourt, Brace and Company, 1995. 
Warren, Rick. The Purpose Driven Church. Grand Rapids, MI: Zondervan Publishing House, 1995.

White, Ellen G. The Desire of Ages. Mountain View, CA: Pacific Press Pub. Assn., 1940.

"The Duty of the Minister." Adventist Review and Sabbath Herald, July 9, 1896.

- Evangelism. Hagerstown, MD: Review and Herald Pub. Assn., 1990.

The Ministry of Healing. Mountain View, CA: Pacific Press Pub. Assn., 1947.

- Testimonies to the Church. Vol. 6. Mountain View, CA: Pacific Press Pub. Assn., 1948.

Williams, Eric. Capitalism and Slavery. New York: Capricorn Books, 1966.

- The Negro in the Caribbean. Westport, CT: Negro Universities Press, 1969. 
VITA

Name: Denton Wayne Rhone

Date and Place of Birth: December 20, 1962, Spanish Town, Jamaica

Education:

1986 Bachelor of Theology, West Indies College, Mandeville, Jamaica

1993 Master of Arts, Andrews University, SDA Theological Seminary, Berrien Springs, Michigan

1996 Doctor of Ministry, Andrews University, SDA Theological Seminary, Berrien Springs, Michigan

Professional Experience:

1986-93 District pastor and evangelist, Central Jamaica Conference

1989-93 Member of Central Jamaica Conference Committee

1992-93 Chaplain, Spaulding Hospital School of Nursing

1994-96 Supervisor, Scholastic Study Lab, Andrews University, Berrien Springs, Michigan

1995- Pastor, Lake Region Conference of SDA, Chicago, Illinois

Evangelism Record:

$$
\text { Baptized - } 949
$$

Special Award:

1993 Pastor of the Year, Central Jamaica Conference 